\title{
Prevalence of leukoencephalopathy and its potential cognitive sequelae in cancer patients
}

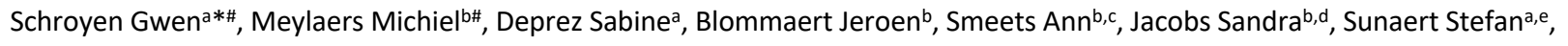
Sleurs Charlotteb,d, Uyttebroeck Anne $e^{b, d}$.
a) Department of Imaging and Pathology KU Leuven, Leuven, Belgium
b) Department of Oncology, KU Leuven, Leuven, Belgium
c) Department of Surgical Oncology, University Hospitals Leuven, Leuven, Belgium
d) Department of Pediatric Hemato-Oncology, University Hospitals Leuven, Leuven, Belgium
e) Department of Radiology, University Hospitals Leuven, Leuven, Belgium

\#Authors contributed equally to the work

*corresponding author

Conflict of interest: none

This research did not receive any specific grant from funding agencies in the public, commercial, or not-for-profit sectors.

Contact corresponding author:

gwen.schroyen@kuleuven.be

+3216345271

Gwen Schroyen, UZ Leuven, Department of Radiology, Herestraat 49, Leuven, Belgium 


\section{ABSTRACT}

Due to the rising use of chemotherapy in cancer patients and growing survival rates, therapy-induced neurotoxic side effects are increasingly reported. Given the ambiguity about the prevalence and severity of leukoencephalopathy, one of such toxic side effects, in non-central nervous system (CNS) cancer patients, we performed a systematic literature search using the PubMed/Medline database to summarize existing literature regarding leukoencephalopathy epidemiology in non-CNS cancer patients and its potential cognitive sequelae. The search was based on the following terms: ('MRI' OR 'T2-weighted MRI' OR 'FLAIR') AND ('cancer' OR 'tumor' OR 'leukemia' OR 'neoplasms') AND ('chemotherapy' OR 'radiotherapy') AND ('posterior reversible encephalopathy' OR 'leukoencephalopathy' OR 'cerebral ischemia' OR 'stroke'). Thirtytwo studies discussing the occurrence of leukoencephalopathy in cancer patients were included, of which the majority investigated Acute Lymphoblastic Leukemia (ALL) patients ( $n=22)$.

Regularly scanned ALL patients showed a prevalence of leukoencephalopathy between $17-87 \%$, and 15 $83 \%$ of patients presented with leukoencephalopathy when only scanned after a CNS event. When diagnosed with posterior reversible encephalopathy syndrome, $100 \%$ of patients showed leukoencephalopathy because its diagnosis is based in part on observable lesions. An increased prevalence was observed in ALL patients treated with higher doses of methotrexate $(5 \mathrm{~g} / \mathrm{m} 2 \mathrm{MTX}, 42$ - 87\%) when compared to lower doses $(<5 \mathrm{~g} / \mathrm{m} 2$, 32 - 67\%). By contrast, in breast cancer patients, white matter lesions were mainly detected in case of neurological symptoms, but not (yet) clearly associated with chemotherapy administration in general. However, chemotherapy treatment was associated with more infratentorial microbleeds in breast cancer patients. Up to $50 \%$ of other (neurologically asymptomatic) solid tumor patients presented white matter lesions, even years after treatment. When cognitive data were investigated, lesioned patients showed lower scores on neurocognitive tests in $50 \%$ of studies, years after ending therapy.

In conclusion, leukoencephalopathy is well-documented for ALL patients (with a focus on methotrexate), but there is a lack of knowledge for other intravenous chemotherapeutics, other oncological populations, wider age ranges and risk factors (e.g. history of CNS event). Furthermore, the long-term neuropsychological impact and potential risk for neurodegenerative processes due to leukoencephalopathy remains inconclusive. Hence, large international databanks, epidemiological and prospective case-control studies are necessary to stratify risk groups for CNS-related side effects.

Keywords: leukoencephalopathy; cancer; chemotherapy; structural; imaging; review

\section{Highlights:}

- Prevalence of leukoencephalopathy in asymptomatic ALL patients ranges from 17 to $87 \%$

- Increased prevalence seen in patients treated with higher doses of methotrexate

- Lower scores on neurocognitive tests after chemotherapy-induced leukoencephalopathy 


\section{INTRODUCTION}

With rising survival rates after cancer treatment, it is becoming increasingly important to assess long-term side effects and consequently ensure quality of life of cancer survivors. Cancer treatment is known to affect both tumor and healthy tissue. Consequently, acute toxic side effects can arise such as cardiotoxicity, neurotoxicity, etc., affecting long-term quality of life. As neurotoxicity can affect brain development throughout the lifespan, neuropsychological research has been conducted increasingly to investigate longterm psychological functioning and accelerated neurodegeneration ${ }^{1}$. Cognitive decline can occur after chemotherapy with a wide spectrum of clinical manifestations, ranging from very subtle to more severe symptoms, including memory, processing speed, attention etc. being affected ${ }^{2}$. Previous research has shown that cognitive side effects can persist up until 10 to 20 years after treatment ${ }^{3,4}$. The number of studies investigating this so-called "chemobrain" keeps expanding ${ }^{5-7}$. However, it remains uncertain to which extent such observed cognitive impairments are reversible ${ }^{8}$, as well as what the exact underlying mechanisms are. Multiple hypotheses of (in)direct pathways of neurotoxicity have been proposed, including inflammation, direct neurotoxicity, oxidative stress, hormonal dysregulation and genetic predisposition ${ }^{9}$. When the developing brain of a child is exposed to such toxicity, these mechanisms have high potential to alter crucial developmental events (e.g. myelination, synaptogenesis, neurogenesis, cortical thinning, and formation of neuronal networks) and cause brain injury ${ }^{10}$.

Due to easier access to magnetic resonance imaging (MRI) and the use of higher chemotherapy doses, leukoencephalopathy, defined as a neurological disease affecting the white matter, is an increasingly observed complication. Leukoencephalopathy is often identified as a symptom of the acute phase of posterior reversible encephalopathy syndrome (PRES), which sometimes recovers ${ }^{11,12}$. The most common clinical features of PRES are seizures with headaches, altered mental status, neurological deterioration and visual impairment. Other possible acute chemotherapy-related neurological complications are dysarthria, hemiplegia, stroke-like episodes, intracranial hemorrhages and cerebellar syndromes $8,11-13$. Such 
neurological complications (e.g. stroke, epilepsy) are associated with white matter damage ${ }^{14}$ and in turn increase the risk for cognitive decline ${ }^{15-19}$.

Generally, white matter lesions are observed as transient hyperintense regions on a T2-weighted MRI, predominantly localized in the subcortical posterior temporal, parietal and occipital white matter, but they can also affect the basal ganglia, cerebellar hemispheres or brainstem. In some cases, additional diffusionweighted MR imaging is needed for diagnosis because of the high signal intensity in the deep white matter ${ }^{11}$. Moreover, diffusion-weighted MR helps to distinguish cytotoxic edema from vasogenic edema. In contrast to cytotoxic edema, vasogenic edema is typically the case in PRES and suggests a reversible process with favorable prognosis ${ }^{13}$. Ultimately, longitudinal acquisition of MR images are preferred for long-term followup of leukoencephalopathy. Given that advanced neuroimaging studies (including microstructural white matter and cortical analyses) are increasingly performed in oncological populations by cognitive neuroscientists ${ }^{20,21}$, the clinical radiological abnormalities (of which leukoencephalopathy is most wellknown in non-central nervous system cancer patients) are highly important to bear in mind for these studies.

Recently, a growing body of literature investigating radiological abnormalities in oncology, such as leukoencephalopathy, has been published. However, most studies investigated childhood Acute Lymphoblastic Leukemia (ALL) ${ }^{22}$, while only few studies focused on other cancer patients. For ALL patients, treatments consistently include methotrexate (MTX), administered both intravenously (IV) and intrathecally (IT). This agent may be a causal factor in the development of encephalopathy ${ }^{23,24}$. In addition to the welldocumented neurotoxicity of MTX, neurotoxic effects of other cytostatics, administered intravenously, such as alkylating substances (i.e. ifosfamide, cyclophosphamide, cisplatin) or vincristine have also been reported 23,25,26. Therefore, we aimed to (1) summarize the existing evidence on the prevalence of leukoencephalopathy in both adult and pediatric non-central nervous system (CNS) cancer patients treated with chemotherapy; (2) stratify these ratios according to age and acute CNS-related adverse events; (3) summarize the evidence on neurocognitive outcomes after leukoencephalopathy.

Given that cranial irradiation can induce substantial cognitive and neurological damage as well ${ }^{27}$, patients receiving such treatment were excluded from this review to disentangle chemotherapy effects, differentiating this manuscript from previous reviews ${ }^{22}$. 


\section{METHODS}

\subsection{Search strategy}

A comprehensive systematic literature search was performed by investigating the PubMed/Medline database with date restrictions from 1995-2019. Subject categories 'MRI', 'cancer', 'therapy' and 'leukoencephalopathy' were searched, by using the following search terms: ('MRI' OR 'T2-weighted MRI' OR 'FLAIR') AND ('cancer' OR 'tumor' OR 'leukemia' OR 'neoplasms') AND ('chemotherapy' OR 'radiotherapy') AND ('posterior reversible encephalopathy' OR 'leukoencephalopathy' OR 'cerebral ischemia' OR 'stroke'). Both studies in children and adults were accepted. Extracted data included patient characteristics, type of cancer, leukoencephalopathy prevalence and cognitive measurements (when investigated).

\subsection{Study selection}

The screening procedure consisted of three different stages. First, potential articles were screened, based on titles. Second, studies were selected by abstract. Third, if the abstract was eligible, full texts were screened. The systematic selection of studies was supplemented with the manual selection of cited references from retrieved articles or other relevant articles. Included in the review were studies (1) with adult or childhood non-CNS cancer patients/survivors, (2) which reported the prevalence of leukoencephalopathy, defined as PRES, ischemia, demyelination, hyperintensities on MR images, white matter lesions or vascular damage, and (3) used at least one post-treatment T2-weighted or Fluid-attenuated Inversion Recovery (FLAIR) MR scan.

Exclusion criteria were: (1) studies published before 1995 (which was indicated in the PubMed/Medline database selection), (2) animal or cell culture studies, (3) case reports with less than 5 cases, (4) studies with patients who received cranial irradiation, (5) pharmacological studies which focused on survival and success rates of new products, (6) studies focusing on diseases other than cancer, (7) studies with MR scans which were not of main interest (e.g. only T1-weighted), (8) studies in which patients did not receive 
chemotherapy,(9) studies with patients diagnosed with CNS tumors and (10) studies with no full English written text available.

\section{RESULTS}

The literature search of the PubMed/Medline database provided 1094 articles. After screening of titles, 1055 articles were removed because they did not meet inclusion criteria. Due to (non-English) language, lack of full-text and duplicate data, 7 articles were additionally excluded after full text screening. A total of 32 articles published between 1997 - 2019 were included in this review (Figure 1). An overview of these articles is provided in Table 1.

\subsection{Prevalence of leukoencephalopathy}

\subsubsection{Leukemia patients}

The majority of the included studies in this review investigated ALL patients, i.e. $22 / 32$ studies $(69 \%)^{12,24,36-}$ 42,28-35. The age at inclusion of ALL patients varied between 1 and 19 years old. No data were available for adult ALL patients. All patients received MTX, both intrathecal (IT) and intravenous (IV). Two studies did not describe the used treatment protocol ${ }^{12,37}$. Depending on the chemotherapy regime, children received either monotherapy with IT-MTX or, as described more recently, triple intrathecal therapy (TIT), which consists of a combination of MTX, cytarabine and prednisolone. The dose of MTX varied between $2 \mathrm{~g} / \mathrm{m}^{2}$ and $5 \mathrm{~g} / \mathrm{m}^{2}$. Only Mahoney et al. (1998) used a lower dose protocol with $1 \mathrm{~g} / \mathrm{m}^{2} \mathrm{MTX}{ }^{42}$. Additional therapy also varied; most frequent additional drugs were oral corticosteroids, vincristine, L-asparaginase, daunorubicin, cyclophosphamide and 6-mercaptopurine.

Some studies scheduled brain imaging of cancer patients on a regular basis, to allow follow-up of leukoencephalopathy. These were planned for example after induction, consolidation, re-induction or at end of therapy. The prevalence in these regularly scanned patients ranged from 17 to $87 \%$, largely depending on 
the sample size and time since diagnosis $30,32,34,36,39$. Long-term follow-up studies reported a decrease in prevalence of leukoencephalopathy from 79 to $27 \%$, assessing ALL patients from 2.6 years to over 15 years after ending therapy ${ }^{30,31,33,40,41,43}$ (see Figure 2).

Eleven out of the 32 studies only described MR images if patients were diagnosed with PRES, and thus $100 \%$ of these cases demonstrated leukoencephalopathy (see Table 1 ) $44,45,54,46-53$. When such patients received a follow-up MR scan, the lesions remained observable in $20 \%$ after two weeks $\mathrm{s}^{50}$ and in $49 \%$ of patients after two months ${ }^{51}$.

A third population of patients was only scanned during therapy at time of a CNS event (eg an epileptic seizure, stroke, visual disturbances, headache, aphasia, changed behavior). This group showed leukoencephalopathy in 26 to $83 \%$ of patients $12,24,28,29,35,38,42$. These hyperintensities were persistent in $36 \%$ of patients 6 months after presenting with PRES, stroke or epilepsy (8 out of 22$)^{35}$ and in all 5 patients investigated $2-39$ months after a stroke-like episode ${ }^{24}$. One study reported radiological normalization of high intensity areas in all ALL patients (6 patients) 1-7 months after ending therapy, who presented with seizures, affective disturbance or other neurological deficits ${ }^{39}$.

Since dose regimens and a combination of multiple cytostatic agents were used across studies, specific agent dose effects are difficult to disentangle. However, two studies did compare low- to high-risk patient populations. Low-risk patients received $2 \mathrm{~g} / \mathrm{m}^{2}$ or $2.5 \mathrm{~g} / \mathrm{m}^{2} \mathrm{IV}$-MTX, while $5 \mathrm{~g} / \mathrm{m}^{2} \mathrm{IV}-\mathrm{MTX}$ was administered in standard- or high risk groups ${ }^{29-31,34-37}$. Patients in the standard- and high-risk groups had a higher prevalence of leukoencephalopathy (42 to $87 \%$ ) than patients in the group with a lower dose of IV-MTX (32 to $67 \%)^{36,38}$. Reddick et al. (2005) concluded that higher doses and more courses of IV-MTX placed patients at higher risk for leukoencephalopathy during treatment ${ }^{36}$. However, Cheung et al. (2016) compared the cumulative doses of agents between patients with and without persistent leukoencephalopathy and found no statistical differences ${ }^{30}$. This discrepancy may be attributed to a threshold effect, since all patients received a cumulative dose of $15 \mathrm{~g} / \mathrm{m}^{2}$ of IV-MTX on average. No difference was found between patients who were treated with TIT versus monotherapy IT-MTX (22 - 76\% versus $37-83 \%$, respectively) ${ }^{12,24,36,38-41,28-35}$. By contrast, Mahoney et al. (1998) showed a significantly higher prevalence of leukoencephalopathy in patients treated with TIT versus mono IT-MTX shortly after a CNS event ${ }^{42}$. 
When evaluating age effects in leukemia patients, Bhojwani et al. (2014) revealed that patients older than 10 years at time of treatment were at a higher risk for neurotoxic events than patients younger than 10 years ${ }^{29}$.

White matter lesions appeared widespread across the brain; predominantly frontal, parietal and occipital regions were affected by encephalopathy $12,24,28,35,39,46,50,53$. Such lesions were also reported in the temporal lobe, semioval nucleus, hippocampus and the thalamus ${ }^{12,28,35,39}$. Uniquely reported lesions are located in the fasciculi or corona radiata ${ }^{30}$ callosal splenium ${ }^{24}$ or in the cerebellum ${ }^{39}$.

\subsubsection{Other cancers}

Eight studies included patients who were diagnosed with other cancers than ALL 12,37,39,43,54-57. First, Koppelmans et al. (2015) described the prevalence of leukoencephalopathy in 187 breast cancer survivors (aged 50-80) 20 years after they had received chemo- (combination of cyclophosphamide, 5-fluoruoracil and oral MTX) and radiotherapy ${ }^{55}$. When compared to age-matched healthy controls, patients showed a higher prevalence of both total cerebral and deep infratentorial microbleeds (MBs), but no increased risk of infarctions or white matter lesions. Additionally, patients with cerebral MBs in deep or infratentorial regions, performed worse on tests of verbal memory and processing speed. Menning et al. (2017) confirmed these results in breast cancer patients (aged <70), 6 months after treatment with anthracycline-based chemotherapy, identifying no significant FLAIR white matter abnormalities. However, they did observe a clear shift from Fazekas score 0 to 1 in all breast cancer patient groups ${ }^{56}$. In contrast, Choi et al. (2001) reviewed clinical records of breast cancer patients treated with a 5-fluorouracil derivative or a combination with 5fluorouracil, cyclophosphamide and epirubicin, and they encountered six patients who developed leukoencephalopathy during chemotherapy on MR images ${ }^{44}$.

Second, childhood Hodgkin lymphoma (HL) patients were investigated in two reports ${ }^{37,43}$. Krull et al. (2012) performed MR imaging in 62 survivors (18-35 years) more than 15 years after diagnosis. The prevalence of leukoencephalopathy was $35 \%$ in the frontal lobe, $13 \%$ in the parietal lobe and $30 \%$ in the centrum semiovale 43. Suzuki et al. (2014) similarly investigated the development of PRES in a population of 161 children with hematological malignancies, including two cases of Hodgkin lymphoma ${ }^{37}$. The two cases were not diagnosed 
with PRES. Given that only PRES patients were summarized in the manuscript, radiographic presentation of white matter lesions alone was not reported.

Third, childhood non-Hodgkin lymphoma (NHL) patients were described in three studies. However, none made any distinction in the used chemotherapy agents ${ }^{12,37,39}$. Zierissen et al. (2005) studied twelve NHL patients and showed that six patients developed abnormal MR findings ${ }^{39}$. By contrast, none of the fifteen NHL cases studied by Suzuki et al. (2014) did develop PRES ${ }^{37}$.

Lastly, Lim et al. (2011) evaluated MR images after a CNS event (not specified which neurological event) in chronic myeloid leukemia, NHL and solid tumors such as osteosarcomas, germ cell tumors and rhabdomyosarcoma. In 6 of these 12 patients (i.e. 50\%), MR images were positive for white matter injuries 12. A more recent study by Sleurs et al. (2019), solely investigating asymptomatic sarcoma survivors at least 2 years after diagnosis, also demonstrated $27 \%$ of survivors showing leukoencephalopathy ${ }^{57}$. Additionally, a higher prevalence (40\%) of white matter lesions was found in patients treated with high dose (HD) MTX IV.

\subsection{Neurocognitive outcome of leukoencephalopathy}

Since leukoencephalopathy affects the white matter, its possible impact on neurocognitive functioning should not be neglected. Eight out of the 32 studies included objective neurocognitive assessments $23,30,31,33,34,40,43,55$.

Compared to population-matched controls ${ }^{30,31,33,34,40,43,55}$ or population norms ${ }^{33}$, all studies concluded that patients had lower scores on neurocognitive tests or had more neurobehavioral problems. Neurocognitive outcome was mostly evaluated using measures of intelligence, attention, executive functioning and memory. Neurobehavioral problems observed after cancer therapy included problems with working memory; initiation, planning and organizing; memory span; executive functions, fine motor functioning and processing speed ${ }^{30,31,33,34,40,43,55,57}$. Only one report described a clear association between higher exposures to IV-MTX and neurocognitive outcomes (executive functioning) in long-term ALL survivors ${ }^{30}$.

All reports but two investigated the relationship between leukoencephalopathy and cognition $30,31,33,40,43,57$. Duffner and colleagues ${ }^{33}$ reported an association between leukoencephalopathy and poorer performance 
on tests of attention and intelligence in a group of ALL survivors 3 years after diagnosis. There were significant differences in specific measures of attention based on presence of leukoencephalopathy, with patients having leukoencephalopathy performing significantly worse on these subtests $(p<0.05)$. Scores more than one standard deviation from the mean of a norm population were considered cognitively impaired. For the different IQ measurements, $64-100 \%$ of the cognitively impaired patients presented with leukoencephalopathy. Additionally, Cheung et al (2016) showed ALL survivors with a history of acute leukoencephalopathy displayed more problems in organization and initiation five years after diagnosis (population norms: $\mathrm{T}=50, \mathrm{SD}=10$; adjusted T-scores patients: $52.2-56.2, p<0.05)^{30}$. Lastly, Nassar et al. (2017) found significant differences in rates of leukoencephalopathy on MRI between ALL patients divided in a seizure and control cohort during ( $56 \%$ vs. $13 \%, p<.01$ ) and at the end of therapy ( $39 \%$ vs. $6 \%, p=.01)$. By contrast, Sabin et al. (2018) ${ }^{31}$ and Kingma et al. (2001) ${ }^{40}$ did not encounter lesion-related outcomes in ALL survivors $>5$ years after completing therapy. However, Sabin et al. (2018) ${ }^{31}$ did find diffusion-weighted imaging parameters (mean diffusivity) in the genu of the corpus callosum $(p=0.04)$, corona radiata $(p=0.02)$, and superior fronto-occipital fasciculi $(p=0.02)$ to be associated with neurocognitive impairment.

Hodgkin lymphoma survivors showing white matter lesions (53\%) also demonstrated a reduced cognitive fluency, more than 15 years after diagnosis compared to population norms $(p=0.001)^{43}$.

While Koppelmans et al. (2015) did not encounter more leukoencephalopathy in chemotherapy-treated breast cancer patients, they did report a lower than expected cognitive performance or cognitive decline in these survivors, 20 years after ending treatment when compared to age-matched controls ( $p<0.03$; odds ratio $1.79-2.25)^{55}$.

Unfortunately, cognitive outcomes in other types of cancer treated with intensive chemotherapy regimens, i.e. neuroblastoma tumors, bone tumors, soft tissue tumors, ... are not investigated thoroughly yet. However, the increasing attention might lead to more small sample studies. For instance, Sleurs et al. (2019) demonstrated that higher Fazekas levels in childhood sarcoma survivors 9 years after diagnosis was associated with longer reaction times during attention tasks $(p<0.05, F>2.9)^{57}$. 


\section{DISCUSSION}

Our study was the first systematic review to describe the prevalence of chemotherapy-induced leukoencephalopathy in all types of cancer throughout the lifespan of patients. Our review shows a high prevalence of leukoencephalopathy after chemotherapy, up to several years after termination of active treatment. Neurocognitive decline was observed in most of studied patients, and lesioned patients scored lower on cognitive tests.

\subsection{Prevalence of leukoencephalopathy}

Leukoencephalopathy is a well-known neurological adverse side effect of chemotherapy. Most studies reviewed here (69\%) were performed in childhood ALL, which is the most common childhood cancer. This is probably due to the fact that ALL is treated with CNS-directed chemotherapy, resulting in an increased risk of CNS complications. Across all types of cancer, we conclude a large variation in prevalence of leukoencephalopathy in patients with (26-83\% of cases) or without (0-87\% of cases) an acute CNS event or presentation of PRES (100\%).

Since multiple CNS events were often investigated together in studies, it is difficult to disentangle which CNS events has the most detrimental and permanent effects. However, leukoencephalopathy persisted months after stroke(-like) episodes ${ }^{24}$, PRES or temporal lobe epilepsy ${ }^{35}$, but not in case of acute seizures, affective disturbance or focal neurological deficits ${ }^{39}$. These results demonstrate that acute neurologic complications can both co-exist with an acute presentation of leukoencephalopathy (and recovery) or permanent presentation of white matter abnormalities, with possible additional neurotoxicity, such as cerebral small vessel disease. In breast cancer patients for instance, cerebral small vessel disease has been reported, with the absence (or recovery) of white matter lesions ${ }^{55}$. 
The location of white matter hyperintensities varied between studies. Lesions appeared across the entire brain including frontal, parietal and occipital regions that were affected by encephalopathy $12,24,28,35,39,46,50,53$.

In most of the reported studies, IV- and IT-MTX administration was considered as the most important risk factor for developing leukoencephalopathy. Some authors reported higher rates of leukoencephalopathy in ALL patients who were treated with more intensive MTX treatments (i.e. higher number of cycles including MTX or higher doses of IV-MTX or TIT MTX) $31,33,36,38,42$. In the study population of Cole et al. (2006) HD-MTX was not included in the treatment protocol, which could explain the lower prevalence of leukoencephalopathy in this specific study ${ }^{32}$. A threshold effect could explain why other studies did not observe this dose-related prevalence. More specifically, once a specific dose intensity or cumulative dose is reached, the effect of treatment on neurological outcomes might be equal ${ }^{30}$. Besides such dose-response relationships, the toxic effects of chemotherapeutic agents might be moderated by neurobiological responses to the treatment (e.g. biomarkers of oxidative stress and inflammation), which also affects the severity of white matter changes ${ }^{30}$. In addition, older age at treatment is an additional risk factor in adult (breast) cancer patients, given the decreased neural integrity and cognitive reserves ${ }^{58,59}$. To which extent these mechanisms play a role in specific oncological populations or treatments, remains inconclusive. In order to address the patient- and treatment-specific risk factors more specifically, large international databanks, epidemiological and case-control studies are highly recommended, comparing the occurrence and degree of leukoencephalopathy in different treatment arms and across a wide age range.

Cancer treatment could also indirectly lead to the development of leukoencephalopathy. Several studies describe the possible side effect of arterial hypertension, due to a corticosteroid treatment or to renal complications ${ }^{13}$. As a result of a higher blood pressure, endothelial damage of the blood brain barrier can cause capillary hypoperfusion and consequent vasogenic edema. This process has been proposed as candidate mechanism for the pathogenesis for PRES ${ }^{35}$. However, the exact sequence of such mechanisms remains unclear ${ }^{12,13,60}$. Furthermore, it needs to be stressed that a rise in blood pressure is not obligatory for the development of PRES ${ }^{12}$. Finally, renal complications or acute renal failure were reported in several 
studies to coincide with the presence of some or all symptoms of PRES ${ }^{12,13,35}$. More specifically, renal complications could delay methotrexate clearance and contribute to neurotoxicity as such ${ }^{61}$.

\subsection{Neurocognitive outcome of leukoencephalopathy}

Almost all reports described patients with lower scores on neurocognitive tests after treatment with chemotherapy (see Table 2). Most reported problems covered tasks that require working memory, initiation, planning and organizing, memory span, executive functions, fine motor functioning and processing speed $30,31,33,34,40,43,55,57$.

While half of the included studies did not find ${ }^{31,34,40}$ (or did not investigate ${ }^{55}$ ) a relationship between cognitive function (during therapy until $>5$ years after ending chemo) and the presence of leukoencephalopathy, four studies did. Survivors of childhood ALL ${ }^{30,33}$, childhood sarcoma ${ }^{57}$ and Hodgkin lymphoma ${ }^{43}$ treated with chemotherapy demonstrated a relationship between more neurobehavioral problems and the presence of leukoencephalopathy when studied 2.6 years ${ }^{30},>5$ years ${ }^{33},>9$ years ${ }^{57}$ and $>15$ years after therapy ${ }^{43}$. This suggests the presence of leukoencephalopathy, or concomitant neurological events, to be indicative for risk of long-term cognitive functioning. In non-cancer populations, neurological insults (and their resulting brain damage) are known to impact cognition; epilepsy (inducing abnormal electrophysiological brain activity), loss of blood supply (inducing ischemic damage), stroke (with vascular damage, microbleeds and possible necrosis $)^{16-19}$. In older individuals, this interplay of cardiovascular diseases, CNS pathology and cognitive impairment becomes even more apparent ${ }^{62}$. Interestingly, only Nassar et al. (2017) ${ }^{34}$ investigated possible CNS events as indicator for cognitive profiles, by dividing patients based on presentation of seizures during therapy. As expected, patients with a history of seizures scored lower on several cognitive tests. Still, future studies are required to unravel the role of CNS events in a patients' susceptibility for cognitive decline, since patients with different neurological profiles (history of stroke, small vessel disease or epilepsy) are also expected to have different cognitive profiles ${ }^{16-19,62}$.

An important consideration, however, remains the discordance between symptoms (acute or long-term) and neuroimaging findings. Cases have been described in which patients did not have any complaints 
despite positive MR images ${ }^{24,33,35}$. Conversely, a number of patients presented with persistent neurological or cognitive symptoms, despite normal radiological findings. This suggests that leukoencephalopathy and cognitive outcomes do not have a one-to-one relationship, but multiple treatment- and patient-specific factors can play an additional role ${ }^{33}$.

For example, since Hodgkin patients are more often diagnosed during adolescence (i.e. later ages than ALL), the impact on cognitive scores which develop earlier might be limited, while education and employment can be affected later in live, being under-reported to date ${ }^{43}$. According to Parasole et al. (2010), PRES will persist in about $10 \%$ of patients, with potentially severe or even fatal neurological disorders ${ }^{35}$. Therefore, a prolonged neurological follow-up time of at least several years is recommended. Unfortunately, the longterm impact of chemotherapy-induced leukoencephalopathy on the development of neurodegenerative diseases at an older age is under-investigated. For adult cancer survivors, a subgroup of elder solid tumor survivors consistently reported difficulties in daily life due to a change in cognitive functioning after treatment for cancer ${ }^{9,59,63}$. How this is associated with the presence of leukoencephalopathy, remains to be unraveled in future research.

The cognitive results suggest that white matter changes during therapy may disrupt long-term brain development, possibly due to altered white matter integrity ${ }^{64}$. Additionally, due to such white matter lesions, the structural connectivity between grey matter areas can be affected, which can explain the observed cognitive deficits after chemotherapy ${ }^{65}$. However, cognitive impairment after chemotherapy is not only caused by anti-cancer drugs, but rather results from complex interactions between patient-specific susceptibility factors (age, cognitive reserve, genetics), tumor-related factors (paraneoplastic, endocrine), non-specific treatments (steroids, psychotropic drugs, anticonvulsants) and specific treatments (surgery, radiotherapy, and chemotherapy) ${ }^{8}$. The frequent use of corticosteroids (i.e. during breast cancer, ALL, NHL and $\mathrm{HL}$ chemotherapy treatment) may possibly be a contributing factor in the development of neurocognitive disturbance ${ }^{40}$.

Given that not all studies demonstrated significant associations between leukoencephalopathy and cognitive decline, leukoencephalopathy alone appears to be insufficient to explain the cognitive decline that can be observed after cancer treatment ${ }^{9}$. Alternatively, other psychological domains or more subtle 
deficits that are associated with acute leukoencephalopathy might not have been adequately measured by the neurocognitive tests used for the abovementioned studies. Additionally, conventional structural MRI years after diagnosis may not adequately predict the lasting neurocognitive effects of acute white matter injury, nor does it quantify microstructural changes due to injury of the myelin or axons. Other imaging approaches, such as diffusion-weighted MRI or myelin water imaging, and estimations of structural connectivity should be considered in subsequent studies to advance our understanding ${ }^{66}$. For example, multiple studies investigating the so-called "chemobrain" in cancer patients report cognitive decline after treatment with chemotherapy to co-exist with white matter differences (e.g. based on diffusion, myelin water and structural imaging), but did not necessarily look at the presence of white matter lesions ${ }^{21,59,67,68}$. Future research unravelling a relationship of presence of leukoencephalopathy in all cancer populations and cognitive decline remains pressing to further define vulnerable populations.

\subsection{Methodological considerations and limitations}

Magnetic resonance images have a fundamental role in the diagnosis and follow-up of leukoencephalopathy in cancer patients. Using T2-weighted or FLAIR scans, radiologists are able to distinguish between white matter lesions and hemorrhagic accidents. For this purpose, the low tissue contrast of CT scans makes them suboptimal, except when large vascular lesions are to be observed ${ }^{35}$. More advanced techniques increasingly receive attention in the diagnostic field, since they are able to improve insights into the development and follow-up of brain damage. For instance, one study investigated diffusion tensor imaging (DTI) parameters, which appeared associated with neurocognitive performance in chemotherapy-treated ALL survivors ${ }^{31}$. Techniques such as functional MR imaging, advanced DWI models, MR spectroscopy or positron emission tomography may provide new opportunities to understand changes in neural signaling and brain functioning ${ }^{40}$. Additionally, new biomarkers will play an important role in future diagnostics and treatment of cancer patients. Firstly, there may be a depletion of folate in the CNS fluid after administration of MTX (both monotherapy and TIT), resulting in an accumulation of phosphorylated tau protein in CNS fluid and an increase of homocysteine in peripheral blood due to decreased remethylation ${ }^{32,42}$. Secondly, neuroinflammation caused by cytokine and interleukin production 
may cause vascular damage with vasogenic edema, promoting the development of white matter lesions ${ }^{37}$. Thirdly, diagnosis-related emotional stress can have a negative influence on the development of leukoencephalopathy and cognitive problems ${ }^{8,69}$. Lastly, the detection of polymorphisms in genes responsible for neurogenesis could help clinicians to predict the patient's susceptibility to leukoencephalopathy in the future ${ }^{29,70}$. The combination of more advanced neuroimaging techniques, detection of biomarkers, identification of genes involving neurogenesis or neuronal plasticity and a universal cognitive assessment protocol, should provide more clarity about long-term effects of leukoencephalopathy in cancer patients in the future. By implementing global evaluation of patients, better follow-up and rehabilitation programs, quality of life of the growing number of survivors of cancer can be enhanced.

The large variability in leukoencephalopathy ratios across studies might partly be explained by the heterogeneity in the lesion rating scales and in sample sizes. As a consequence, it was impossible to standardize the definition or grade of leukoencephalopathy. Therefore, it will become important to investigate larger international databases which provide clearly defined criteria or ratings for leukoencephalopathy (e.g. FAERS, VigiBase, Eudravigilance, EORTC). These databases also contain more recent chemotherapeutic protocols in contrast to survivor studies included in this literature review. Secondly, most studies reported childhood ALL. Data were only minimally available for adult patients, other chemotherapeutics than MTX, other cancers than leukemia, and older ages. However, because of the large group of ALL patients included in this study, the treatment is broadly uniform allowing fair comparisons for this cancer group.

The most important implication resulting from this review is to bring awareness to clinical personnel and neuroscientists, in order to provide information to cancer patients on expected neurotoxic side effects. Although the aggressiveness of the disease and survival of patients is still the first concern of the physician, knowledge on expected sequelae after treatment can only improve clinical guidance of patients and future research improving this. 


\section{CONCLUSION}

The central nervous system is very susceptible to complications of cancer and its systemic treatment. With the exception of childhood ALL studies, there is a lack of research concerning the prevalence of leukoencephalopathy in patients treated for other cancers, receiving other chemotherapeutics and over a spectrum of ages. Sufficiently large, prospective follow-up studies will be necessary to determine the prevalence and long-term clinical neurocognitive effects of leukoencephalopathy in cancer patients, as well as analyzing international databases for observable adverse drug effects. Earlier identification using more advanced neuroimaging techniques, detailed CNS event administration, and neurological biomarkers may allow healthcare professionals to define risk groups in more detail, which will guide the physician in patienttailored treatment decisions. Finally, intervention techniques and preventive measures against CNS-related side effects should receive more attention in future studies. 


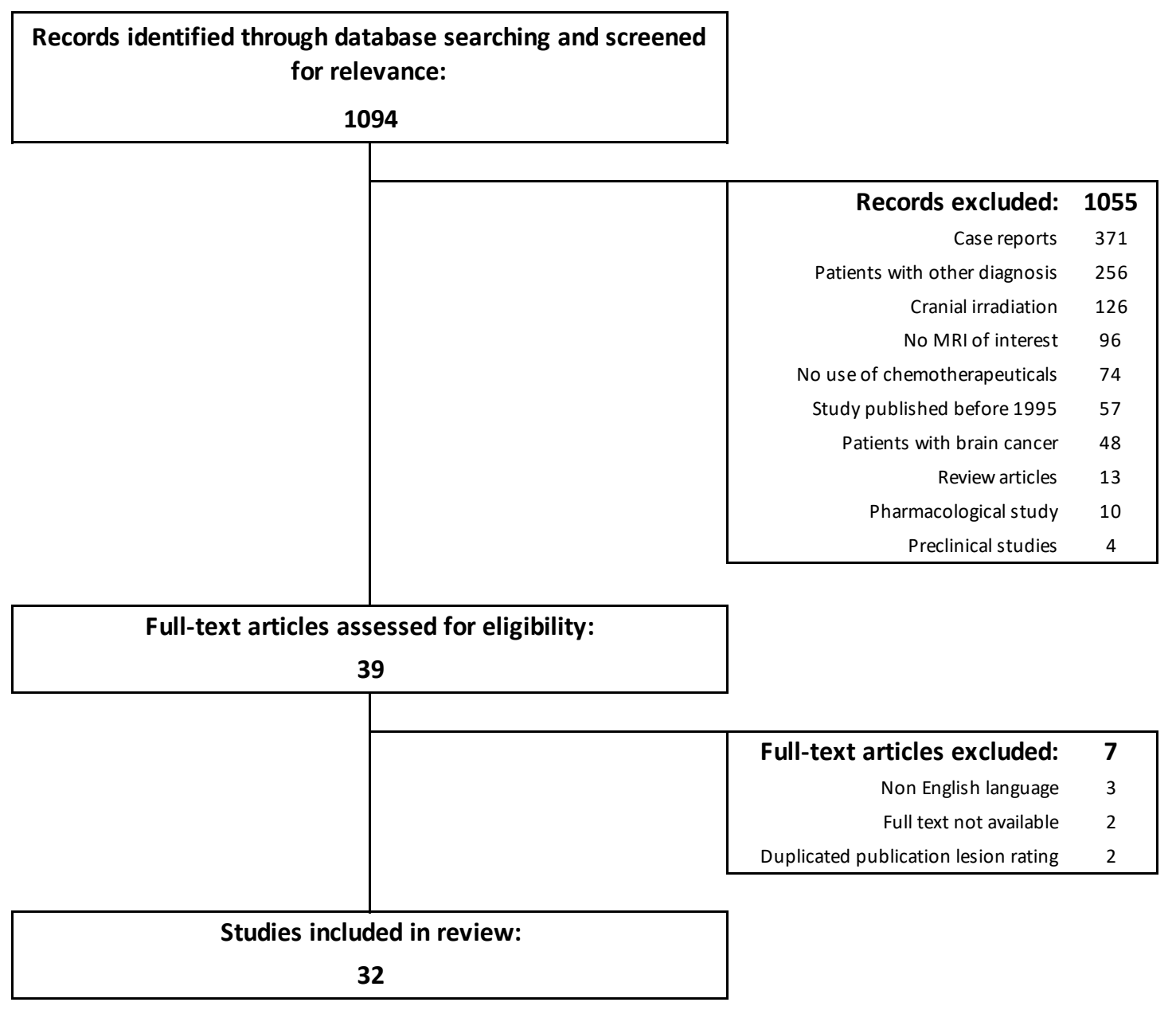

Figure 1. Flow diagram of the systemic review. 


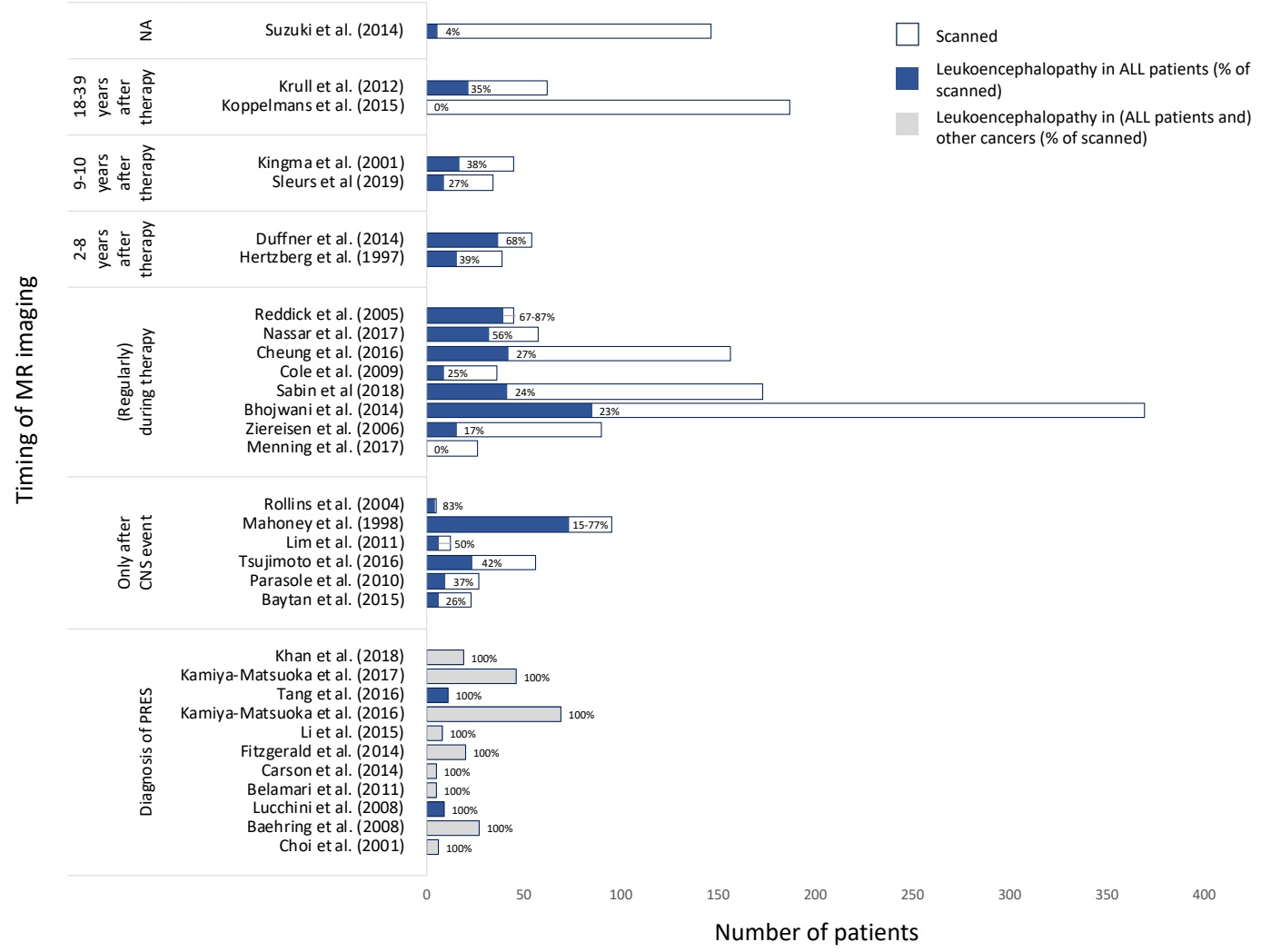

Figure 2. Prevalence of leukoencephalopathy on magnetic resonance images during or after cancer chemotherapy.

ALL: Acute Lymphoblastic Leukemia, CNS: central nervous system, NA: no data available about timing of MR imaging, PRES: posterior reversible encephalopathy syndrome 
Table 1. Overview of included studies

\begin{tabular}{|c|c|c|c|c|c|c|c|c|c|c|}
\hline \multirow{2}{*}{$\begin{array}{l}\text { Author } \\
\text { (year) }\end{array}$} & \multirow{2}{*}{ Type cancer } & \multirow{2}{*}{$\begin{array}{l}\text { Current age } \\
\text { (mean/median } \\
\text { years) }\end{array}$} & \multirow{2}{*}{$\begin{array}{c}\# \\
\text { patients }\end{array}$} & \multicolumn{3}{|c|}{ Chemotherapeutical } & \multirow{2}{*}{ MR sequence } & \multirow{2}{*}{ Timing MR scan } & \multirow{2}{*}{ Regions } & \multirow{2}{*}{ Prevalence } \\
\hline & & & & IT & HD-MTX & Other & & & & \\
\hline $\begin{array}{l}\text { Hertzberg } \\
\text { et al. (1997) }\end{array}$ & ALL & 15 & 39 & Mono MTX & $2 \mathrm{~g} / \mathrm{m} 2$ & NA & $\mathrm{T} 2, \mathrm{PD}$ & 7 years after diagnosis & NA & $39 \%$ \\
\hline \multirow{3}{*}{$\begin{array}{l}\text { Mahoney et } \\
\text { al. (1998) }\end{array}$} & \multirow{3}{*}{ ALL } & \multirow{3}{*}{ Children } & 543 & \multirow{3}{*}{$\begin{array}{l}\text { 1x TIT and } \\
12 x \text { IT MTX }\end{array}$} & $1 \mathrm{~g} / \mathrm{m} 2$ & $\begin{array}{c}\text { A: VCR, L-ASP, prednisolone + } \\
\text { IM MTX }\end{array}$ & \multirow{3}{*}{$\mathrm{T} 2$} & \multirow{3}{*}{ after CNS event (seizure) } & \multirow{3}{*}{ NA } & $\begin{array}{c}8 \% \text { of total population presented with CNS } \\
\text { event (A: } 8 \%, B: 4 \%, C: 11 \%)\end{array}$ \\
\hline & & & 354 & & / & $\begin{array}{l}\text { B: VCR, L-ASP, prednisolone + } \\
\text { Oral MTX + IM MTX, 6-MP }\end{array}$ & & & & B:15\% if CNS event \\
\hline & & & 321 & & $1 \mathrm{~g} / \mathrm{m} 2$ & $\begin{array}{c}\text { C: VCR, L-ASP, prednisolone + } \\
\text { IM MTX, 6-MP (dose less than } \\
\text { regimen A) }\end{array}$ & & & & C: $77 \%$ if CNS event \\
\hline $\begin{array}{l}\text { Choi et al. } \\
\text { (2001) }\end{array}$ & Breast cancer & $46 \pm 10$ & 6 & / & / & $\begin{array}{l}\text { 5-FU, CPM, epirubicin, } \\
\text { carmofur }\end{array}$ & $\mathrm{T} 1, \mathrm{~T} 2$ & NA & periventricular & $100 \% *$ \\
\hline $\begin{array}{l}\text { Kingma et } \\
\text { al. (2001) }\end{array}$ & ALL & 11 & 45 & $\begin{array}{l}\text { mono MTX + } \\
\text { prednisolone }\end{array}$ & $2 \mathrm{~g} / \mathrm{m} 2$ & $\begin{array}{l}\text { oral MTX, cytarabine } \\
\text { arabinoside }\end{array}$ & NA & 10 years after diagnosis & NA & $\begin{array}{l}38 \% \text { ( } 50 \% \text { definitely abnormal, } 50 \% \\
\text { probably abnormal) }\end{array}$ \\
\hline $\begin{array}{l}\text { Rollins et al. } \\
\text { (2004) }\end{array}$ & ALL & $14 \pm 1$ & 194 & Mono MTX & $\begin{array}{l}\text { After IT (IV } \\
\text { MTX) }\end{array}$ & $\begin{array}{c}\text { DEXA, VCR, L-ASP, DNR, 6-MP, } \\
\text { Ara-C, CPM and/or oral MTX }\end{array}$ & $\begin{array}{l}\text { T1, T2, FLAIR, } \\
\text { ADC map }\end{array}$ & $\begin{array}{c}\text { within } 17-23 \text { hours } \\
\text { after CNS event, } 2-39 \\
\text { months later (stroke-like } \\
\text { episode) }\end{array}$ & $\begin{array}{c}\text { cerebral atrophy and } \\
\text { callosal splenium - } \\
\text { frontal and parietal } \\
\text { lobe }\end{array}$ & $\begin{array}{c}3 \% \text { of total population presented with CNS } \\
\text { event, } 83 \% \text { if CNS event (from those, } 20 \% \\
\text { at follow-up) }\end{array}$ \\
\hline $\begin{array}{l}\text { Reddick et } \\
\text { al. (2005) }\end{array}$ & ALL & 5 & 45 & TIT & $\begin{array}{l}2.5 \mathrm{~g} / \mathrm{m} 2 \\
\text { or } 5 \mathrm{~g} / \mathrm{m} 2\end{array}$ & / & T1, T2, FLAIR & $\begin{array}{l}\text { week } 6,7,31 \text { and } 120 \\
\text { after start therapy }\end{array}$ & NA & $76 \%(87 \% \text { in high risk, } 67 \% \text { in low risk })^{3}$ \\
\hline $\begin{array}{l}\text { Ziereisen et } \\
\text { al. (2006) }\end{array}$ & ALL & Children & 90 & $\begin{array}{l}\text { TIT or mono } \\
\text { MTX }\end{array}$ & $5 \mathrm{~g} / \mathrm{m} 2$ & $\begin{array}{l}\text { VCR, PRED or DEXA, DNR, L- } \\
\text { ASP, CMP, Ara-C, 6-MP or 6-TG }\end{array}$ & $\begin{array}{l}\text { T1, T2, FLAIR, } \\
\text { ADC map (6 } \\
\text { patients) }\end{array}$ & $\begin{array}{l}\text { after therapy, after } \\
\text { relapse and after CNS } \\
\text { event (seizure, affective } \\
\text { disturbance or focal } \\
\text { neurological deficits) }\end{array}$ & $\begin{array}{l}\text { frontal, parietal, } \\
\text { occipital, } \\
\text { supratentorial ctx, } \\
\text { cerebellar ctx and } \\
\text { thalamus }\end{array}$ & $17 \%$ (0\% after $1-7$ months) \\
\hline \multirow{3}{*}{$\begin{array}{l}\text { Baehring et } \\
\text { al. (2008) }\end{array}$} & $\begin{array}{l}\text { ALL or large cell } \\
\text { lymphoma }\end{array}$ & $14 \pm 3$ & 19 & mono MTX & \multirow[b]{3}{*}{ NA } & NA & \multirow{3}{*}{$\begin{array}{l}\text { T2, FLAIR, DWI, } \\
\text { ADC map }\end{array}$} & \multirow[b]{3}{*}{ NA } & \multirow[b]{3}{*}{ NA } & \multirow[b]{3}{*}{$100 \% *$} \\
\hline & Breast cancer & $44 \pm 5$ & 4 & NA & & capecitabine & & & & \\
\hline & $\begin{array}{l}\text { Cancer of (sigmoid-) } \\
\text { colon, nasopharynx, } \\
\text { pancreas }\end{array}$ & $54 \pm 22$ & 4 & NA & & capecitabine, 5-FU, carmofur & & & & \\
\hline $\begin{array}{l}\text { Lucchini et } \\
\text { al. (2008) }\end{array}$ & ALL & 5 & 9 & NA & NA & NA & T2, FLAIR & $\begin{array}{c}\text { Within } 24 \text { hours of CNS } \\
\text { event }\end{array}$ & $\begin{array}{l}\text { (sub)cortical in } \\
\text { occipital, frontal, } \\
\text { parietal and } \\
\text { temporal areas }\end{array}$ & $100 \% *$ \\
\hline
\end{tabular}




\begin{tabular}{|c|c|c|c|c|c|c|c|c|c|c|}
\hline $\begin{array}{l}\text { Cole et al. } \\
\text { (2009) }\end{array}$ & ALL & Children & 36 & TIT & I & MTX or aminopterine per os & $\mathrm{T} 1, \mathrm{~T} 2$, FLAIR & 45 days after therapy & $\begin{array}{l}\text { periventricular or } \\
\text { subcortical white } \\
\text { matter lesions }\end{array}$ & $25 \%$ \\
\hline $\begin{array}{l}\text { Parasole et } \\
\text { al. (2010) }\end{array}$ & ALL & 6 & 253 & mono MTX & $\begin{array}{l}\text { none, } 2 \\
\mathrm{~g} / \mathrm{m} 2 \text { or } \\
5 \mathrm{~g} / \mathrm{m} 2\end{array}$ & $\begin{array}{l}\text { DEXA, VCR, DNR, L-ASP, VDS, } \\
\text { IFO, 6-MP }\end{array}$ & T1, T2, FLAIR & $\begin{array}{l}\text { at time of CNS event and } \\
6 \text { months after event } \\
\text { (PRES, stroke, temporal } \\
\text { lobe epilepsy and other) }\end{array}$ & $\begin{array}{l}\text { frontal, parietal, } \\
\text { occipital, } \\
\text { hippocampal and } \\
\text { semioval nucleus } \\
\text { areas }\end{array}$ & $\begin{array}{c}4 \% \text { of total population presented with CNS } \\
\text { event, } 37 \% \text { if CNS event (from those, } 36 \% \\
\text { after } 6 \text { months) }\end{array}$ \\
\hline \multirow{2}{*}{$\begin{array}{l}\text { Belaramani } \\
\text { et al. (2011) }\end{array}$} & ALL & 7 & 4 & NA & NA & $\begin{array}{l}\text { MTX, DEXA, DXR, VCR, L-ASP, } \\
\text { cytarabine }\end{array}$ & \multirow{2}{*}{ NA } & $\begin{array}{l}\text { within } 1 \text { week after } \\
\text { event (seizure) }\end{array}$ & \multirow{2}{*}{ NA } & \multirow{2}{*}{$100 \% *$} \\
\hline & $\begin{array}{l}\text { Pituitary germ cell } \\
\text { tumor }\end{array}$ & 7 & 1 & / & / & BEP & & NA & & \\
\hline $\begin{array}{l}\text { Lim et al. } \\
\text { (2011) }\end{array}$ & $\begin{array}{l}\text { ALL, AML, CML, NHL, } \\
\text { solid tumors }\end{array}$ & 10 & 12 & NA & NA & NA & FLAIR & $\begin{array}{c}\text { after CNS event } \\
\text { (definition not specified) }\end{array}$ & $\begin{array}{l}\text { frontal, parietal, } \\
\text { temporal, occipital }\end{array}$ & $50 \%$ \\
\hline $\begin{array}{l}\text { Krull et al. } \\
(2012)\end{array}$ & HL & $42 \pm 5$ & 62 & l & I & $\begin{array}{l}\text { doxorubicin and/or } \\
\text { anthracyclines and/or } \\
\text { bleomycin }\end{array}$ & T1, T2, FLAIR, PD & $\begin{array}{c}>15 \text { years after } \\
\text { diagnosis }\end{array}$ & $\begin{array}{l}\text { frontal and parietal } \\
\text { lobe and semioval } \\
\text { nucleus }\end{array}$ & $\begin{array}{c}35 \% \text { frontal, } 13 \% \text { parietal, } 30 \% \text { semioval } \\
\text { nucleus }\end{array}$ \\
\hline $\begin{array}{l}\text { Bhojwani et } \\
\text { al. (2014) }\end{array}$ & ALL & Children & 369 & TIT & $\begin{array}{l}2.5 \mathrm{~g} / \mathrm{m} 2 \\
\text { (low risk) } \\
\text { or } 5 \mathrm{~g} / \mathrm{m} 2 \\
\text { (high risk) }\end{array}$ & $\begin{array}{c}\text { oral MTX, DEXA, VCR, CPM or } \\
\text { cytarabine }\end{array}$ & T1, T2, FLAIR, PD & $\begin{array}{l}\text { postinduction, } 1 \text { week } \\
\text { after re-induction } \\
\text { (cons.), } 48 \text { weeks after } \\
\text { cont., } 120 \text { weeks after } \\
\text { cont., during or after } \\
\text { CNS event (seizure, } \\
\text { stroke, behavioral } \\
\text { changes, aphasia) }\end{array}$ & NA & $\begin{array}{l}23 \% \text { (persisted in } 74 \% \text { of asymptotic and } \\
58 \% \text { of symptomatic patients until end of } \\
\text { therapy) }\end{array}$ \\
\hline \multirow{3}{*}{$\begin{array}{l}\text { Carson et } \\
\text { al. (2014) }\end{array}$} & HL & $49 \pm 2$ & 3 & \multirow{3}{*}{ / } & \multirow{3}{*}{ I } & $\begin{array}{l}\text { BV, DXR, bleomycin, } \\
\text { vinblastine, dacarbazine, IFO, } \\
\text { carboplatine, ETO, methyl- } \\
\text { PRED, cytarabine, cisplatin }\end{array}$ & \multirow{3}{*}{ NA } & \multirow{3}{*}{ NA } & \multirow{3}{*}{ NA } & \multirow{3}{*}{$100 \% *$} \\
\hline & $\begin{array}{l}\text { Primary cutaneous } \\
\text { anaplastic large cell } \\
\text { Iymphoma }\end{array}$ & 38 & 1 & & & $\begin{array}{l}\text { BV, topical CS, MTX, } \\
\text { bexarotene, IFN-alpha, } \\
\text { vorinostat }\end{array}$ & & & & \\
\hline & $\begin{array}{l}\text { Transformed } \\
\text { mycosis fungoides }\end{array}$ & 72 & 1 & & & $\begin{array}{l}\text { BV, topical CS, phototherapy, } \\
\text { IFN-alpha, bexarotene, } \\
\text { localized RT }\end{array}$ & & & & \\
\hline \multirow{2}{*}{$\begin{array}{l}\text { Duffner et } \\
\text { al. (2014) }\end{array}$} & \multirow{2}{*}{ ALL } & \multirow{2}{*}{12} & 31 & $\begin{array}{l}\text { TIT and } \\
\text { mono MTX }\end{array}$ & $\begin{array}{l}\text { After IT } \\
\text { (1a) }\end{array}$ & $\mathrm{MP}+$ oral MTX & \multirow{2}{*}{ T1, T2, FLAIR } & \multirow{2}{*}{$\begin{array}{l}>2.6 \text { years following end } \\
\text { of treatment }\end{array}$} & \multirow{2}{*}{$\begin{array}{c}\text { centrum semiovale, } \\
\text { periventricular white } \\
\text { matter }\end{array}$} & \multirow{2}{*}{$68 \%$ mild, $3 \%$ moderate, $2 \%$ severe ( 2 ) } \\
\hline & & & 23 & $\begin{array}{l}\text { TIT and } \\
\text { mono MTX }\end{array}$ & $\begin{array}{l}\text { Concurrent } \\
\text { with IT (1b) }\end{array}$ & I & & & & \\
\hline \multirow[t]{2}{*}{$\begin{array}{l}\text { Fitzgerald } \\
\text { et al. (2014) }\end{array}$} & MM & \multirow[t]{2}{*}{60} & 12 & \multirow[t]{2}{*}{ / } & \multirow[t]{2}{*}{ / } & $\begin{array}{l}\text { bortezomib, DXR, thalidomide, } \\
\text { carmustine, ETO, cytarabine, } \\
\text { melphalan, cisplatin, } \\
\text { (tem)sirolimus, DEXA, } \\
\text { rituximab, adriamycin, } \\
\text { carfilzomib or CPM }\end{array}$ & \multirow[t]{2}{*}{ NA } & \multirow[t]{2}{*}{ NA } & \multirow[t]{2}{*}{ NA } & \multirow[t]{2}{*}{$100 \% *$} \\
\hline & Other solid tumors & & 8 & & & $\begin{array}{l}\text { wide range of different } \\
\text { chemotherapeuticals }\end{array}$ & & & & \\
\hline
\end{tabular}




\begin{tabular}{|c|c|c|c|c|c|c|c|c|c|c|}
\hline \multirow{4}{*}{$\begin{array}{l}\text { Suzuki et al. } \\
\qquad(2014)\end{array}$} & $\mathrm{HL}$ & \multirow{4}{*}{5} & 2 & NA & NA & $\begin{array}{c}\text { steroids, VCR, CPM, THP- } \\
\text { adriamycin, L-ASP, actinomycin } \\
\text { D, MTX, cytarabine }\end{array}$ & \multirow{4}{*}{ T2, FLAIR } & \multirow{4}{*}{ NA } & \multirow{4}{*}{ NA } & \multirow{4}{*}{$4 \%$} \\
\hline & AML & & 36 & NA & NA & cytarabine, ETO, mitoxantrone & & & & \\
\hline & ALL & & 108 & / & $\begin{array}{l}2 \mathrm{~g} / \mathrm{m} 2 \text { or } \\
5 \mathrm{~g} / \mathrm{m} 2\end{array}$ & oral MTX, DEXA, VCR, 6-MP & & & & \\
\hline & $\mathrm{NHL}$ & & 15 & NA & NA & $\begin{array}{c}\text { steroids, VCR, CPM, THP- } \\
\text { adriamycin, L-ASP, actinomycin } \\
\text { D, MTX, cytarabine }\end{array}$ & & & & \\
\hline $\begin{array}{l}\text { Baytan et } \\
\text { al. (2015) }\end{array}$ & ALL & 7 & 323 & $\begin{array}{l}\text { TIT and } \\
\text { mono MTX }\end{array}$ & $5 \mathrm{~g} / \mathrm{m} 2$ & $\begin{array}{c}\text { PRED, VCR, DNR, L-ASP, } \\
\text { cytarabine, CPM, IFO, DEXA, } \\
\text { ETO }\end{array}$ & T2, FLAIR & $\begin{array}{l}\text { after CNS event } \\
\text { (convulsion, blindness, } \\
\text { aphasia, headache or } \\
\text { facial nerve paralysis) }\end{array}$ & $\begin{array}{l}\text { parietal and occipital } \\
\text { lobe }\end{array}$ & $\begin{array}{l}6 \% \text { of total population presented with CNS } \\
\text { event, } 83 \% \text { if CNS event }\end{array}$ \\
\hline $\begin{array}{l}\text { Koppelmans } \\
\text { et al. (2015) }\end{array}$ & Breast cancer & $64 \pm 7$ & 187 & I & / & $\begin{array}{l}\text { CMP, oral MTX and 5- } \\
\text { fluorouracil }\end{array}$ & $\begin{array}{l}\text { T1, T2 GRE, } \\
\text { FLAIR }\end{array}$ & $\begin{array}{l}>20 \text { years after end of } \\
\text { treatment }\end{array}$ & NA & $\begin{array}{l}\text { No difference in white matter lesions, } \\
\text { cortical or lacunar infarctions and lobar } \\
\text { microbleeds. More infratentorial } \\
\text { microbleeds. }\end{array}$ \\
\hline $\begin{array}{l}\text { Li et al. } \\
\text { (2015) }\end{array}$ & ALL, lymphoma & 7 & 8 & NA & NA & NA & $\mathrm{T} 1, \mathrm{~T} 2$ & NA & $\begin{array}{l}\text { parietal, occipital, } \\
\text { frontal, temporal } \\
\text { regions or } \\
\text { combinations }\end{array}$ & $100 \%$ (from those, $20 \%$ after 2 weeks) * \\
\hline $\begin{array}{l}\text { Cheung et } \\
\text { al. (2016) }\end{array}$ & ALL & $14 \pm 4$ & 156 & TIT & $\begin{array}{l}2.5 \mathrm{~g} / \mathrm{m} 2 \\
\text { (low risk) } \\
\text { or } 5 \mathrm{~g} / \mathrm{m} 2 \\
\text { (standard } \\
\text { or high } \\
\text { risk) }\end{array}$ & $\begin{array}{l}\text { DEXA, L-ASP, CPM, DNR, DXR, } \\
\text { VCR, mercaptopurine }\end{array}$ & T2, FLAIR, DWI & $\begin{array}{l}\text { week 6-7 (ind.), week } 1 \\
\text { after re-ind. (cons.), } \\
\text { week } 1 \text { after re-ind. } \\
\text { (cons.), week } 48 \text { (after } \\
\text { cont.), week } 120 \text { (at end } \\
\text { of therapy), after } 5 \text { years }\end{array}$ & NA & $27 \%$ (from those, $78 \%$ after 5 years) \\
\hline $\begin{array}{l}\text { Kamiya- } \\
\text { Matsuoka } \\
\text { et al. (2016) }\end{array}$ & Leukemia and others & 52 & 69 & NA & NA & $\begin{array}{l}\text { tacrolimus, DXR, VCR, DEXA, } \\
\text { different monoclonal } \\
\text { antibodies }\end{array}$ & $\begin{array}{l}\text { T1, T2, FLAIR, } \\
\text { DWI, ADC map }\end{array}$ & NA & $\begin{array}{l}\text { parietal and occipital } \\
\text { lobes }\end{array}$ & $100 \%$ (from those, $49 \%$ after 8 weeks) * \\
\hline $\begin{array}{l}\text { Tang et al. } \\
\text { (2016) }\end{array}$ & ALL & $9 \pm 2$ & 11 & NA & NA & $\begin{array}{l}\text { MTX, cytarabine, DNR, VCR, L- } \\
\text { ASP, prednisolone }\end{array}$ & T1, T2, FLAIR & $0,1,3,6$ and 12 months & $\begin{array}{l}\text { parietal and occipital } \\
\text { lobe }\end{array}$ & $100 \% *$ \\
\hline \multirow[b]{2}{*}{$\begin{array}{l}\text { Tsujimoto } \\
\text { et al. (2016) }\end{array}$} & \multirow[b]{2}{*}{ ALL } & \multirow[b]{2}{*}{5} & 25 & \multirow[b]{2}{*}{ TIT } & $<5 \mathrm{~g} / \mathrm{m} 2$ & Oral MTX & \multirow[b]{2}{*}{ T1, T2, FLAIR } & \multirow{2}{*}{$\begin{array}{l}\text { Before start of therapy } \\
\text { and at time of CNS event } \\
\text { (seizure, delirium, } \\
\text { stroke-like episode) }\end{array}$} & \multirow[b]{2}{*}{ NA } & $32 \%$ \\
\hline & & & 31 & & $5 \mathrm{~g} / \mathrm{m} 2$ & l & & & & $42 \%$ \\
\hline $\begin{array}{l}\text { Kamiya- } \\
\text { Matsuoka } \\
\text { et al. (2017) }\end{array}$ & $\begin{array}{l}\text { Primary } \\
\text { hematological and } \\
\text { solid tumor }\end{array}$ & $50 \pm 20$ & 46 & I & / & CPM, VCR, DXR (most used) & $\begin{array}{l}\text { T1, T2, FLAIR, } \\
\text { DWI, ADC map }\end{array}$ & NA & NA & $100 \% *$ \\
\hline $\begin{array}{l}\text { Menning et } \\
\text { al. (2017) }\end{array}$ & Breast cancer & $51 \pm 7$ & 26 & NA & NA & $\begin{array}{l}\text { doxorubicin, } \\
\text { cyclophosphamide, 5- } \\
\text { fluorouracil, epirubicin, } \\
\text { cyclophosphamide }\end{array}$ & T1, FLAIR, DWI & $\begin{array}{l}\text { after surgery, } 6 \text { months } \\
\text { after ending therapy }\end{array}$ & NA & $0 \%$ \\
\hline
\end{tabular}




\begin{tabular}{|c|c|c|c|c|c|c|c|c|c|c|}
\hline $\begin{array}{l}\text { Nassar et al. } \\
\quad(2017)\end{array}$ & ALL & $8 \pm 5$ & 57 & TIT & $\begin{array}{c}2.5 \mathrm{~g} / \mathrm{m} 2 \\
\text { (low risk) } \\
\text { or } 5 \mathrm{~g} / \mathrm{m} 2 \\
\text { (standard } \\
\text { and high } \\
\text { risk) }\end{array}$ & $\begin{array}{l}\text { MTX, mercaptopurine, } \mathrm{VCR} \text {, } \\
\text { DEXA }\end{array}$ & T1, T2, FLAIR & $\begin{array}{l}\text { week } 5 \text { after ind. - week } \\
7 \text { after cons. - week } 120 \\
\text { at end of therapy }\end{array}$ & NA & $\begin{array}{c}\text { week } 5,7,120: 0 \%, 56 \%, 39 \% \text { in high risk vs } \\
0 \%, 13 \%, 6 \% \text { in low risk }\end{array}$ \\
\hline $\begin{array}{l}\text { Khan et al. } \\
\text { (2018) }\end{array}$ & $\begin{array}{l}\mathrm{NHL}, \mathrm{ALL}, \mathrm{HL} \text {, Ewing } \\
\text { sarcoma }\end{array}$ & 7 & 19 & TIT $(n=16)$ & Oral MTX & $\begin{array}{c}\text { carboplatin, CPM, } \\
\text { daunorubicin, DEXA, etoposide, } \\
\text { ifosfamide, vincristine }\end{array}$ & $\begin{array}{l}\text { T2, FLAIR, T2 } \\
\text { GRE, DWI and T1 } \\
\text { pre- and } \\
\text { postcontrast }\end{array}$ & $\begin{array}{l}\text { At time of CNS event } \\
\text { (seizures, visual loss or } \\
\text { altered mental state) }\end{array}$ & $\begin{array}{l}\text { bilateral symmetrical } \\
\text { subcortical white } \\
\text { matter involvement } \\
\text { of the occipital and } \\
\text { parietal lobes }\end{array}$ & $\begin{array}{c}100 \% \text { ( } 1.6 \% \text { in total population of children } \\
\text { with leukemia and } 0.28 \% \text { in those with } \\
\text { solid tumors) * }\end{array}$ \\
\hline $\begin{array}{l}\text { Sabin et al } \\
\text { (2018) }\end{array}$ & ALL & $14 \pm 5$ & 173 & TIT & $\begin{array}{c}2.5 \mathrm{~g} / \mathrm{m} 2 \\
\text { (low risk) } \\
\text { or } 5 \mathrm{~g} / \mathrm{m} 2 \\
\text { (standard } \\
\text { and high } \\
\text { risk) }\end{array}$ & oral MTX, DEXA, cytarabine & $\begin{array}{l}\text { T1, T2, FLAIR, } \\
\text { PD, DWI }\end{array}$ & $\begin{array}{l}\text { during therapy and }>5 \\
\text { years after diagnosis }\end{array}$ & $\begin{array}{c}\text { supra- or } \\
\text { periventricular white } \\
\text { matter }\end{array}$ & $24 \%$ (from those, $79 \%$ after 5 years) \\
\hline $\begin{array}{l}\text { Sleurs et al. } \\
\text { (2019) }\end{array}$ & $\begin{array}{l}\text { Ewing, (non-) } \\
\text { Rhabdomyosarcoma, } \\
\text { osteosarcoma }\end{array}$ & 21 & 34 & I & $0-144 \mathrm{~g} / \mathrm{m} 2$ & $\begin{array}{l}\text { alkylating agents (ifosfamide, } \\
\text { cyclophosphamide); } \\
\text { doxorubicin, cisplatin }\end{array}$ & FLAIR & 9 years after diagnosis & NA & $27 \%$ \\
\hline
\end{tabular}

* these studies only included patients based on clinical presentation of leukoencephalopathy and thus have a prevalence of $100 \%$.

(1) 1a: children received standard MTX (20 mg/m² IM) weekly, 1b: received divided dose MTX (25 $\mathrm{mg} / \mathrm{m}^{2}$ PO Q 6 hours X 4 every other week) (1) 1a: children received standard MTX (20 mg/m² IM) weekly, 1 b: received divided dose MTX (25 $\mathrm{mg} / \mathrm{m}^{2}$ PO Q 6 hours X 4 every other week)
(2) Mild: mild diffuse T2 hyperintensities in the periventricular white matter/centrum semiovale); Moderate: moderate T2 hyperintensities involving confluent deep white matter from the frontal horns to the trigone, which may

extend to the subcortical U-fibers.
(3) Low risk: patients in which the plasma steady-state concentration of MTX was $33 \mu \mathrm{mol} / \mathrm{L}$; High risk: patients in which the plasma steady-state concentration of MTX was $65 \mu \mathrm{mol} / \mathrm{L}$.

ADC: apparent diffusion coefficient; ALL: acute lymphoblastic leukemia; Ara-C: cytocine arabinoside; B-ALL: B-lymphocyte ALL; BEP: triple chemotherapy with bleomycin, etoposide and cisplatin; BV: brentuximab vedotin (monoclonal antibody targeting CD30-positive cells); cons.: consolidation; cont.: continuation; CNS: central nerve system; CPM: cyclophosphamide; CS: corticosteroids; ctx: cortex; DEXA: dexamethasone; diff. difference; DNR: daunorubicin; DWI: diffusion weighted imaging; DTI: diffusion tensor imaging; DXR: doxorubicin; ETO: etoposide; FLAIR: fluid attenuated inversion recovery; HD-MTX: High-dose methotrexate (> 0,5 g/m²); HL: Hodgkin lymphoma; ); IFN- $\alpha$ : interferon alpha; IFO: ifosfamide; ind.: induction; IM: intramuscular; IT: Intrathecal; L-ASP: L-asparaginase; MM: multiple myeloma; MP: mercaptopurine; MR: magnetic resonance; MTX: methotrexate; NA: data not available; NHL: Non-Hodgkin Iymphoma; PD: proton density weighted sequence; PRED: prednisolone; RT: radiotherapy; T-ALL: T-lymphocyte ALL; TIT: triple intrathecal therapy with MTX, cytarabine and prednisolone; T2 GRE: T2-weighted gradient recalled echo accelerated MR images; VCR: vincristine; VDS: vindesine; 5-FU: 5-fluorouracil; 6-MP: 6-mercaptopurine; 6-TG: 6-thioguanine 


\begin{tabular}{|c|c|c|c|c|c|c|c|c|}
\hline Autor (year) & $\begin{array}{l}\text { Cancer } \\
\text { type }\end{array}$ & $\begin{array}{l}\text { Current age } \\
\text { (mean/medi } \\
\text { an years) }\end{array}$ & $\begin{array}{c}\# \\
\text { patients }\end{array}$ & Groups & Timing NPA & Function measures & Results & Correlation with MRI leukoencephalopathy? \\
\hline $\begin{array}{l}\text { Kingma et al. } \\
\text { (2001) }\end{array}$ & ALL & 5 & 45 & $\begin{array}{l}17 \text { chemo vs } 28 \\
\text { chemo+CR vs } \\
225 \text { age-matched } \\
\text { controls }\end{array}$ & $\begin{array}{l}\text { 3-6 months after } \\
\text { cessation of chemo } \\
\text { and } 5 \text { years later }\end{array}$ & $\begin{array}{l}\text { intelligence, attention, } \\
\text { memory, visual motor } \\
\text { integration, fine motor } \\
\text { functioning }\end{array}$ & $\begin{array}{l}\text { After } 5 \text { years: chemo patients scored lower than controls } \\
\text { on memory ( } M=9.5 \text { vs } 10.0 \text { ) and fine motor functioning } \\
\text { ( } M=9.1 \text { vs } 10.0) \text {. Chemo+CR scored lower than chemo } \\
\text { patients on intelligence, attention and fine motor } \\
\text { functioning. School levels differed between chemo+CR } \\
\text { patients and siblings, but not between chemo-only patients } \\
\text { and siblings. }\end{array}$ & $\begin{array}{c}\text { No significant associations } \\
\text { were found between MRI outcome } \\
\text { and test scores, school placement, or education } \\
\text { level in either group. More abnormal MRI findings in chemo+CR } \\
\text { than chemo only ( } 63 \% \text { vs } 38 \% \text { ). }\end{array}$ \\
\hline $\begin{array}{l}\text { Krull et al. } \\
\text { (2012) }\end{array}$ & $\begin{array}{l}\text { Hodgkin } \\
\text { lymphoma }\end{array}$ & $42 \pm 5$ & 62 & $\begin{array}{l}\text { chemo+TR vs } \\
\text { norms }\end{array}$ & $\begin{array}{c}>15 \text { years after } \\
\text { diagnosis }\end{array}$ & $\begin{array}{l}\text { intelligence, attention, } \\
\text { memory, processing } \\
\text { speed and executive } \\
\text { functioning }\end{array}$ & $\begin{array}{l}\text { Compared to published norms, } 12 \%-46 \% \text { of patients } \\
\text { showed cognitive impairments; with lower performance on } \\
\text { sustained attention, short-term- , long-term- and working } \\
\text { memory, naming speed and cognitive fluency (\% impaired } \\
\text { defined as 1SD below the normative mean). }\end{array}$ & $\begin{array}{l}\text { Lower cognitive fluency was demonstrated in survivors with } \\
\text { leukoencephalopathy ( } \mathrm{M} Z=-0.92 ; S D=0.97) \text { in the centrum } \\
\text { semiovale compared with those without leukoencephalopathy } \\
\qquad(\mathrm{M} Z=-0.05 ; S D=0.81) \text {. }\end{array}$ \\
\hline $\begin{array}{l}\text { Duffner et } \\
\text { al. (2014) }\end{array}$ & ALL & 13 & 52 & chemo vs norms & $\begin{array}{l}>2.6 \text { years after } \\
\text { end of treatment }\end{array}$ & $\begin{array}{l}\text { intelligence, attention } \\
\text { and concentration, } \\
\text { memory, processing } \\
\text { speed and executive } \\
\text { functioning }\end{array}$ & $\begin{array}{l}\text { Compared to published norms, } 40 \% \text { of patients showed } \\
\text { deficits on intelligence scores (i.e. VIQ or PIQ scores }<85 \text { ) } \\
\text { and }>16 \% \text { of patients had attention problems (\% impaired } \\
\text { defined as } 1 \text { SD below the normative mean). }\end{array}$ & $\begin{array}{l}\text { The majority }(75 \%-100 \%) \text { of children treated with } \\
\text { chemotherapy who scored }>1 \text { SD worse than the normative } \\
\text { mean on areas of specific neurocognitive function also had } \\
\text { leukoencephalopathy. }\end{array}$ \\
\hline $\begin{array}{l}\text { Koppelmans } \\
\text { et al. (2015) }\end{array}$ & $\begin{array}{l}\text { Breast } \\
\text { cancer }\end{array}$ & $64 \pm 7$ & 187 & $\begin{array}{l}\text { chemo+ } \\
\text { radiotherapy vs } \\
374 \text { age-matched } \\
\text { controls }\end{array}$ & $\begin{array}{l}>20 \text { years after } \\
\text { end of treatment }\end{array}$ & $\begin{array}{l}\text { memory, word fluency, } \\
\text { processing speed, } \\
\text { executive functioning, } \\
\text { visuospatial ability and } \\
\text { manual dexterity }\end{array}$ & $\begin{array}{l}\text { Previously published }{ }^{4} \text { : women exposed to chemotherapy } \\
\text { performed significantly worse than the reference group on } \\
\text { cognitive tests of immediate and delayed verbal memory } \\
\text { processing speed, executive functioning and psychomotor } \\
\text { speed }(-0.40<Z<-0.05) \text {. }\end{array}$ & $\begin{array}{l}\text { Association with cognition was not investigated. They did find } \\
\text { that patients with cerebral microbleeds in deep or infratentorial } \\
\text { regions -but not with strictly lobar cerebral microbleeds- } \\
\text { performed worse than reference participants on tests of verbal } \\
\text { memory and processing speed (odds ratio } 1.79-2.25 \text { ). }\end{array}$ \\
\hline $\begin{array}{l}\text { Cheung et al. } \\
\text { (2016) }\end{array}$ & ALL & $19 \pm 4$ & 190 & $\begin{array}{l}190 \text { chemo vs } \\
\text { norms }\end{array}$ & $\begin{array}{c}>5 \text { years after } \\
\text { diagnosis }\end{array}$ & $\begin{array}{l}\text { intelligence, attention, } \\
\text { memory, processing } \\
\text { speed, executive } \\
\text { functioning and fine } \\
\text { motor dexterity }\end{array}$ & $\begin{array}{c}\text { Compared to published norms, survivors were } 1.6 \text { to } 3.2 \\
\text { times more likely to demonstrate problems across all } \\
\text { neurobehavioral domains and demonstrated more parent- } \\
\text { reported problems with working memory, organization, } \\
\text { initiation and planning. }\end{array}$ & $\begin{array}{l}\text { Survivors with a history of acute leukoencephalopathy displayed } \\
\text { more neurobehavioral problems than survivors with no history } \\
\text { on parent-reported organization (adjusted T-score } 56.2 \text { vs } 52.2 \text { ) } \\
\text { and initiation ( } 55.5 \text { vs } 52.1 \text { (norms } \mathrm{T}=50, \mathrm{SD}=10 \text { ), while } \\
\text { no difference was observed for neurocognitive performance. }\end{array}$ \\
\hline $\begin{array}{l}\text { Nassar et al. } \\
\text { (2017) }\end{array}$ & ALL & $8 \pm 5$ & 57 & $\begin{array}{l}19 \text { chemo on- } \\
\text { therapy seizure } \\
\text { children vs } 38 \\
\text { chemo non- } \\
\text { seizure children } \\
\text { vs norms }\end{array}$ & $\begin{array}{l}\text { week } 6 \text { induction } \\
\text { (initial } \\
\text { assessment), end } \\
\text { of therapy (week } \\
120 \text { continuation) } \\
\text { and two years post } \\
\text { therapy } \\
\text { completion }\end{array}$ & $\begin{array}{l}\text { intelligence, attention, } \\
\text { memory, processing } \\
\text { speed and academic skills }\end{array}$ & $\begin{array}{l}\text { Compared to the no-seizure patients, the seizure group } \\
\text { performed worse on attention ( } M=79.43 \text { vs } 101.17 \text { ), } \\
\text { working memory tasks ( } M=6.00 \text { vs } 10.04 \text { ), processing } \\
\text { speed deficits ( } M=88.57 \text { vs } 103.92 \text { ) and overall intelligence } \\
\text { ( } M=88.92 \text { vs 101). }\end{array}$ & $\begin{array}{c}\text { Association with cognition was not investigated. } \\
\text { They did find significant differences in rate of } \\
\text { leukoencephalopathy on MRI between the seizure and the } \\
\text { control cohort groups at week } 7 \text { ( } 56 \% \text { vs } 13 \% \text { ) and at the end of } \\
\text { therapy (39\% vs } 6 \% \text { ) }\end{array}$ \\
\hline $\begin{array}{l}\text { Sabin et al. } \\
\text { (2018) }\end{array}$ & ALL & $14 \pm 5$ & 173 & chemo vs norms & $\begin{array}{c}>5 \text { years after } \\
\text { diagnosis }\end{array}$ & $\begin{array}{l}\text { intelligence, attention, } \\
\text { memory, processing } \\
\text { speed, executive } \\
\text { functioning and fine } \\
\text { motor dexterity }\end{array}$ & $\begin{array}{l}\text { Compared to published norms, } 10 \%-48 \% \text { of patients } \\
\text { showed cognitive impairments; with lower scores on } \\
\text { measures of executive function }(0.20<Z<-0.53) \text {, memory } \\
\quad(Z=-0.42) \text {, processing speed }(-0.40<Z<-1.29) \\
\text { and global intelligence }(Z=-0.14) \text { (\% impaired defined as a } \\
\text { score }<10^{\text {th }} \text { percentile of the age-adjusted } Z \text { score) }\end{array}$ & $\begin{array}{l}\text { Association with cognition was not found. They did find DTI } \\
\text { parameters (mean diffusivity) in the genu of the corpus } \\
\text { callosum, corona radiata, and superior fronto-occipital fasciculi } \\
\text { to be associated with neurocognitive impairment. }\end{array}$ \\
\hline
\end{tabular}




\begin{tabular}{|c|c|c|c|c|c|c|c|c|}
\hline $\begin{array}{l}\text { Sleurs et al. } \\
\text { (2019) }\end{array}$ & $\begin{array}{l}\text { Ewing-, } \\
\text { (non-) } \\
\text { rhabdomy } \\
\text { o- and } \\
\text { osteo- } \\
\text { sarcoma }\end{array}$ & 21 & 34 & $\begin{array}{l}\text { chemo vs } 34 \\
\text { controls }\end{array}$ & $\begin{array}{c}>2 \text { years after } \\
\text { diagnosis }\end{array}$ & $\begin{array}{l}\text { intelligence, attention } \\
\text { and verbal and visual } \\
\text { memory }\end{array}$ & $\begin{array}{l}\text { Compared to controls, patients showed lower quality of life } \\
(\mathrm{M}=1645 \text { vs } 1913) \text {, working memory }(M=97.94 \text { vs } 109.12) \text {, } \\
\text { processing speed ( } M=99.45 \text { vs } 107.38 \text { ) and visual memory. }\end{array}$ & $\begin{array}{l}\text { Leukoencephalopathy prevalence was related to attentional } \\
\text { processing speed. }\end{array}$ \\
\hline
\end{tabular}

ALL: acute lymphoblastic leukemia, CR: cranial radiation, DTI: Diffusion Tensor Imaging, M: mean, non-B-ALL: non-B-lymphocyte ALL, TR: thoracic radiation 


\section{REFERENCES}

Schagen SB, Muller MJ, Boogerd W, et al. Late effects of adjuvant chemoth
patients. Ann Oncol. 2002;13(9):1387-1397. doi:10.1093/annonc/mdf24

2.

Seigers R, Fardell JE. Neurobiological basis of chemotherapy-induced cognitive impairment: A review of rodent research. Neurosci Biobehav Rev. 2011;35(3):729-741. doi:10.1016/j.neubiorev.2010.09.006

3. de Ruiter MB, Reneman L, Boogerd W, et al. Late effects of high-dose adjuvant chemotherapy on white and gray matter in breast cancer survivors: Converging results from multimodal magnetic resonance imaging. Hum Brain Mapp. 2012;33(12):2971-2983. doi:10.1002/hbm.21422

4. Koppelmans V, Breteler MMB, Boogerd W, Seynaeve C, Gundy C, Schagen SB. Neuropsychological Performance in Survivors of Breast Cancer More Than 20 Years After Adjuvant Chemotherapy. J Clin Oncol. 2012;30(10):1080-1086. doi:10.1200/JCO.2011.37.0189

5. Vardy J, Wefel JS, Ahles T, Tannock IF, Schagen SB. Cancer and cancer-therapy related cognitive dysfunction: an international perspective from the Venice cognitive workshop. Ann Oncol. 2007;19(4):623-629. doi:10.1093/annonc/mdm500

6. Kim HJ, Jung SO, Kim H, Abraham I. Systematic review of longitudinal studies on chemotherapy-associated subjective cognitive impairment in cancer patients. Psychooncology. February 2020. doi:10.1002/pon.5339

7. Deprez S, Kesler SR, Saykin AJ, Silverman DHS, de Ruiter MB, McDonald BC. International Cognition and Cancer Task Force Recommendations for Neuroimaging Methods in the Study of Cognitive Impairment in Non-CNS Cancer Patients. JNCI J Nat/ Cancer Inst. 2018;110(3):223-231. doi:10.1093/jnci/djx285

8. Soussain C, Ricard D, Fike JR, Mazeron J-J, Psimaras D, Delattre J-Y. CNS complications of radiotherapy and chemotherapy. Lancet. 2009;374(9701):1639-1651. doi:10.1016/S0140-6736(09)61299-X

9. Ahles TA, Root JC. Cognitive Effects of Cancer and Cancer Treatments. Annu Rev Clin Psychol. 2018;14(5):1-527. doi:10.1146/annurevclinpsy-050817

10. Ikonomidou C. Chemotherapy and the pediatric brain. Mol Cell Pediatr. 2018. doi:10.1186/s40348-018-0087-0

11. Cabaj A, Bekiesińska-Figatowska M, Duczkowska A, Duczkowski M. Brain MRI Findings in Neurological Complications of Cancer Treatment. Adv Clin Exp Med. 2016;25(4):789-797.

12. Lim Y-J, Kim H-J, Lee Y-J, Seol I-J, Lee Y-H. Clinical Features of Encephalopathy in Children With Cancer Requiring Cranial Magnetic Resonance Imaging. Pediatr Neurol. 2011;44(6):433-438. doi:10.1016/j.pediatrneurol.2011.01.007

13. Morris EB, Laningham FH, Sandlund JT, Khan RB. Posterior reversible encephalopathy syndrome in children with cancer. Pediatr Blood Cancer. 2007;48(2):152-159. doi:10.1002/pbc.20703

14. Matute C, Ransom BR. Roles of white matter in central nervous system pathophysiologies. ASN Neuro. 2012;4(2):89-101. doi:10.1042/AN20110060

15. Tang EYH, Amiesimaka O, Harrison SL, et al. Longitudinal effect of stroke on cognition: A systematic review. J Am Heart Assoc. 2018;7(2). doi:10.1161/JAHA.117.006443

16. Saa JP, Tse T, Baum C, et al. Longitudinal evaluation of cognition after stroke - A systematic scoping review. PLoS One. 2019;14(8). doi:10.1371/journal.pone.0221735

17. Brainin M, Tuomilehto J, Heiss WD, et al. Post-stroke cognitive decline: An update and perspectives for clinical research. Eur J Neurol. 2015;22(2):229-238. doi:10.1111/ene.12626

18. Fonseca Wald ELA, Hendriksen JGM, Drenthen GS, et al. Towards a Better Understanding of Cognitive Deficits in Absence Epilepsy: a Systematic Review and Meta-Analysis. Neuropsychol Rev. 2019;29(4):421-449. doi:10.1007/s11065-019-09419-2

19. Malkki H. Cerebrovascular disorders: Cerebral microbleeds linked to increased risk of cognitive decline. Nat Rev Neurol. $2016 ; 12(8): 432$. doi:10.1038/nrneurol.2016.94

20. Simó M, Rifà-Ros X, Rodriguez-Fornells A, Bruna J. Chemobrain: A systematic review of structural and functional neuroimaging studies. Neurosci Biobehav Rev. 2013;37(8):1311-1321. doi:10.1016/j.neubiorev.2013.04.015

21. Li M, Caeyenberghs K. Longitudinal assessment of chemotherapy-induced changes in brain and cognitive functioning: A systematic review. Neurosci Biobehav Rev. May 2018. doi:10.1016/j.neubiorev.2018.05.019

22. Partap S, Russo S, Esfahani B, et al. A Review of Chronic Leukoencephalopathy among Survivors of Childhood Cancer. Pediatr Neurol. 2019;18:31330-31334. doi:10.1016/J.PEDIATRNEUROL.2019.03.006

23. Sleurs C, Deprez S, Emsell L, Lemiere J, Uyttebroeck A. Chemotherapy-induced neurotoxicity in pediatric solid non-CNS tumor patients: An update on current state of research and recommended future directions. Crit Rev Oncol Hematol. 2016;103:37-48. doi:10.1016/J.CRITREVONC.2016.05.001

24. Rollins N, Winick N, Bash R, Booth T. Acute methotrexate neurotoxicity: findings on diffusion-weighted imaging and correlation with clinical outcome. AJNR Am J Neuroradiol. 2004;25(10):1688-1695.

25. Kesler SR, Blayney DW. Neurotoxic Effects of Anthracycline- vs Nonanthracycline-Based Chemotherapy on Cognition in Breast Cancer Survivors. JAMA Oncol. 2016;2(2):185-192. doi:10.1001/jamaoncol.2015.4333

26. Yang M, Moon C. Neurotoxicity of cancer chemotherapy. Neural Regen Res. 2013;8(17):1606-1614. doi:10.3969/j.issn.16735374.2013.17.009

Cole $\mathrm{PD}$ Kamen BA. Delayed neurotoxicity associated with therapy for children with acute lymphoblastic leukemia. Ment Retard Dev Disabil Res Rev. 2006;12(3):174-183. doi:10.1002/mrdd.20113

28. Baytan B, Evim MS, Güler S, Güneş AM, Okan M. Acute Central Nervous System Complications in Pediatric Acute Lymphoblastic Leukemia. Pediatr Neurol. 2015;53(4):312-318. doi:10.1016/j.pediatrneurol.2015.03.006

29. Bhojwani D, Sabin ND, Pei D, et al. Methotrexate-induced neurotoxicity and leukoencephalopathy in childhood acute lymphoblastic leukemia. J Clin Oncol. 2014:32(9):949-959. doi:10.1200/JC0.2013.53.0808

30. Cheung YT, Sabin ND, Reddick WE, et al. Leukoencephalopathy and long-term neurobehavioural, neurocognitive, and brain imaging outcomes in survivors of childhood acute lymphoblastic leukaemia treated with chemotherapy: a longitudinal analysis. Lancet Haematol. 2016;3(10):e456-e466. doi:10.1016/S2352-3026(16)30110-7

31. Sabin ND, Cheung YT, Reddick WE, et al. The Impact of Persistent Leukoencephalopathy on Brain White Matter Microstructure in Long-Term Survivors of Acute Lymphoblastic Leukemia Treated with Chemotherapy Only. Am J Neuroradiol. 2018. doi:10.3174/ajnr.A5791

32. Cole PD, Beckwith KA, Vijayanathan V, Roychowdhury S, Smith AK, Kamen BA. Folate homeostasis in cerebrospinal fluid during therapy for acute lymphoblastic leukemia. Pediatr Neurol. 2009;40(1):34-41. doi:10.1016/j.pediatrneurol.2008.09.005 
Duffner PK, Armstrong FD, Chen L, et al. Neurocognitive and Neuroradiologic Central Nervous System Late Effects in Children Treated on Pediatric Oncology Group (POG) P9605 (Standard Risk) and P9201 (Lesser Risk) Acute Lymphoblastic Leukemia Protocols (ACCL0131). J Pediatr Hematol Oncol. 2014;36(1):8-15. doi:10.1097/MPH.0000000000000000

34. Nassar SL, Conklin HM, Zhou Y, et al. Neurocognitive outcomes among children who experienced seizures during treatment for acute lymphoblastic leukemia. Pediatr Blood Cancer. 2017;64(8). doi:10.1002/pbc.26436

35. Parasole R, Petruzziello F, Menna G, et al. Central nervous system complications during treatment of acute lymphoblastic leukemia in a single pediatric institution. Leuk Lymphoma. 2010;51(6):1063-1071. doi:10.3109/10428191003754608

36. Reddick WE, Glass JO, Helton KJ, et al. Prevalence of leukoencephalopathy in children treated for acute lymphoblastic leukemia with highdose methotrexate. AJNR Am J Neuroradiol. 2005;26(5):1263-1269.

37. Suzuki D, Kobayashi R, Iguchi A, et al. Tumor lysis syndrome as a risk factor for posterior reversible encephalopathy syndrome in children with hematological malignancies. Int J Hematol. 2014;100(5):485-489. doi:10.1007/s12185-014-1658-z Tsujimoto S-I, Yanagimachi M, Tanoshima R, et al. Influence of ADORA2A gene polymorphism on leukoencephalopathy risk in MTX-treated pediatric patients affected by hematological malignancies. Pediatr Blood Cancer. 2016;63(11):1983-1989. doi:10.1002/pbc.26090

Ziereisen F, Dan B, Azzi N, Ferster A, Damry N, Christophe C. Reversible acute methotrexate leukoencephalopathy: atypical brain MR imaging features. Pediatr Radiol. 2006;36(3):205-212. doi:10.1007/s00247-005-0015-z

40. Kingma A, Van Dommelen RI, Mooyaart EL, Wilmink JT, Deelman BG, Kamps WA. Slight cognitive impairment and magnetic resonance imaging abnormalities but normal school levels in children treated for acute lymphoblastic leukemia with chemotherapy only. $J$ Pediatr. 2001;139(3):413-420. doi:10.1067/mpd.2001.117066

41. Hertzberg H, Huk WJ, Ueberall MA, et al. CNS late effects after ALL therapy in childhood. Part I: Neuroradiological findings in long-term survivors of childhood ALL--an evaluation of the interferences between morphology and neuropsychological performance. The German Late Effects Working Group. Med Pediatr Oncol. 1997;28(6):387-400.

42. Mahoney DH, Shuster JJ, Nitschke R, et al. Acute neurotoxicity in children with B-precursor acute lymphoid leukemia: an association with intermediate-dose intravenous methotrexate and intrathecal triple therapy--a Pediatric Oncology Group study. J Clin Oncol. 1998;16(5):1712-1722. doi:10.1200/JCO.1998.16.5.1712

43. Krull KR, Sabin ND, Reddick WE, et al. Neurocognitive Function and CNS Integrity in Adult Survivors of Childhood Hodgkin Lymphoma. J Clin Oncol. 2012;30(29):3618-3624. doi:10.1200/JCO.2012.42.6841

Choi SM, Lee SH, Yang YS, Kim BC, Kim MK, Cho KH. 5-fluorouracil-induced leukoencephalopathy in patients with breast cancer. J Korean Med Sci. 2001;16(3):328-334. doi:10.3346/jkms.2001.16.3.328

45. Baehring JM, Fulbright RK. Delayed leukoencephalopathy with stroke-like presentation in chemotherapy recipients. J Neurol Neurosurg Psychiatry. 2008;79(5):535-539. doi:10.1136/jnnp.2007.123737

46. Lucchini G, Grioni D, Colombini A, et al. Encephalopathy syndrome in children with hemato-oncological disorders is not always posterior and reversible. Pediatr Blood Cancer. 2008;51(5):629-633. doi:10.1002/pbc.21688

47. Belaramani KM, Lai V, Li CH, Lee ACW, Kwong NS. Reversible posterior leukoencephalopathy syndrome in Chinese children induced by chemotherapy: a review of five cases. Hong Kong Med J = Xianggang yi xue za zhi. 2011;17(1):61-66.

Carson KR, Newsome SD, Kim EJ, et al. Progressive multifocal leukoencephalopathy associated with brentuximab vedotin therapy: a report of 5 cases from the Southern Network on Adverse Reactions (SONAR) project. Cancer. 2014;120(16):2464-2471. doi:10.1002/cncr.28712

Fitzgerald RT, Wright SM, Samant RS, et al. Elevation of serum lactate dehydrogenase at posterior reversible encephalopathy syndrome onset in chemotherapy-treated cancer patients. J Clin Neurosci. 2014;21(9):1575-1578. doi:10.1016/J.JOCN.2014.03.004

50. Li H, Liu Y, Chen J, et al. Posterior reversible encephalopathy syndrome in patients with hematologic tumor confers worse outcome. World J Pediatr. 2015;11(3):245-249. doi:10.1007/s12519-015-0027-1

51. Kamiya-Matsuoka C, Paker AM, Chi L, Youssef A, Tummala S, Loghin ME. Posterior reversible encephalopathy syndrome in cancer patients: a single institution retrospective study. J Neurooncol. 2016;128(1):75-84. doi:10.1007/s11060-016-2078-0

52. Kamiya-Matsuoka C, Tummala S. Electrographic patterns in patients with posterior reversible encephalopathy syndrome and seizures. $J$ Neurol Sci. 2017;375:294-298. doi:10.1016/J.JNS.2017.02.017

53.

Tang J-H, Tian J-M, Sheng M, et al. Study of Posterior Reversible Encephalopathy Syndrome in Children With Acute Lymphoblastic Leukemia After Induction Chemotherapy. J Child Neurol. 2016;31(3):279-284. doi:10.1177/0883073815589758

54. Khan SJ, Arshad AA, Fayyaz MB, ud din Mirza I. Posterior Reversible Encephalopathy Syndrome in Pediatric Cancer: Clinical and Radiologic Findings. J Glob Oncol. 2018;(4):1-8. doi:10.1200/jgo.17.00089

55. Koppelmans V, Vernooij MW, Boogerd W, et al. Prevalence of Cerebral Small-Vessel Disease in Long-Term Breast Cancer Survivors Exposed to Both Adjuvant Radiotherapy and Chemotherapy. J Clin Oncol. 2015;33(6):588-593. doi:10.1200/JC0.2014.56.8345

56. Menning S, De Ruiter MB, Veltman DJ, et al. Changes in brain white matter integrity after systemic treatment for breast cancer: a prospective longitudinal study. Brain Imaging Behav. 2017;12(2):324-334. doi:10.1007/s11682-017-9695-x

57. Sleurs C, Lemiere J, Radwan A, et al. Long-term leukoencephalopathy and neurocognitive functioning in childhood sarcoma patients treated with high-dose intravenous chemotherapy. Pediatr Blood Cancer. 2019;66(10). doi:10.1002/pbc.27893

Ahles TA, Saykin Al, McDonald BC, et al Longitudinal assessment of cognitive changes associated with adjuvant treatment for breast cancer: impact of age and cognitive reserve. J Clin Oncol. 2010;28(29):4434-4440. doi:10.1200/JCO.2009.27.0827

59. Blommaert J, Schroyen G, Vandenbulcke M, et al. Age-dependent brain volume and neuropsychological changes after chemotherapy in breast cancer patients. Hum Brain Mapp. August 2019:hbm.24753. doi:10.1002/hbm.24753

60. Panis B, Vlaar AMM, van Well GTJ, et al. Posterior reversible encephalopathy syndrome in paediatric leukaemia. Eur J Paediatr Neurol. 2010;14(6):539-545. doi:10.1016/j.ejpn.2010.01.003

61. Atra A, Pinkerton CR, Bouffet E, et al. Acute neurotoxicity in children with advanced stage B-non-Hodgkin's lymphoma and B-acute lymphoblastic leukaemia treated with the United Kingdom children cancer study group 9002/9003 protocols. Eur J Cancer. 2004;40(9):13461350. doi:10.1016/J.EJCA.2004.02.011

62. Sen A, Capelli V, Husain M. Cognition and dementia in older patients with epilepsy. Brain. 2018;141:1592-1608. doi:10.1093/brain/awy022

63. Deprez S, Vandenbulcke M, Peeters R, et al. Longitudinal Assessment of Chemotherapy-Induced Alterations in Brain Activation During Multitasking and Its Relation With Cognitive Complaints. J Clin Oncol. 2014;32(19):2031-2038. doi:10.1200/JCO.2013.53.6219

64. Schuitema I, Deprez S, Van Hecke W, et al. Accelerated aging, decreased white matter integrity, and associated neuropsychological dysfunction 25 years after pediatric lymphoid malignancies. J Clin Oncol. 2013;31(27):3378-3388. doi:10.1200/JCO.2012.46.7050

65. Dietrich J, Han R, Yang Y, Mayer-Pröschel M, Noble M. CNS progenitor cells and oligodendrocytes are targets of chemotherapeutic agents in vitro and in vivo. J Biol. 2006;5(7):22. doi:10.1186/jbiol50

66. Horowitz TS, Suls J, Treviño M. A Call for a Neuroscience Approach to Cancer-Related Cognitive Impairment. Trends Neurosci. 2018;41(8):493-496. doi:10.1016/j.tins.2018.05.001

67. Billiet T, Emsell L, Vandenbulcke $\mathrm{M}$, et al. Recovery from chemotherapy-induced white matter changes in young breast cancer survivors? Brain Imaging Behav. January 2017. doi:10.1007/s11682-016-9665-8

68. Thibo Billiet IECSAURDJLSD. Brain Connectivity and Cognitive Flexibility in Nonirradiated Adult Survivors of Childhood Leukemia. JNCI J Nat Cancer Inst. 2018;110(8):905-913. doi:10.1093/jnci 
69. Ahles TA, Saykin AJ. Candidate mechanisms for chemotherapy-induced cognitive changes. Nat Rev Cancer. 2007;7(3):192-201. doi:10.1038/nrc2073

70. Sleurs C, Madoe A, Lagae L, et al. Genetic Modulation of Neurocognitive Development in Cancer Patients throughout the Lifespan: a Systematic Review. Neuropsychol Rev. 2019;29(2):190-219. doi:10.1007/s11065-019-09399-3 